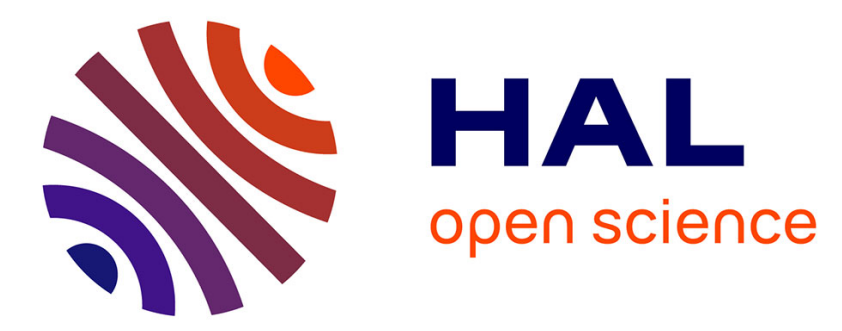

\title{
A Simple and Efficient Approach toward Photosensitive Biobased Aliphatic Polycarbonate Materials
}

Pierre-Luc Durand, Antoine Brège, Guillaume Chollet, Etienne Grau, Henri Cramail

\section{- To cite this version:}

Pierre-Luc Durand, Antoine Brège, Guillaume Chollet, Etienne Grau, Henri Cramail. A Simple and Efficient Approach toward Photosensitive Biobased Aliphatic Polycarbonate Materials. ACS Macro Letters, 2018, 7 (2), pp.250-254. 10.1021/acsmacrolett.8b00003 . hal-01917959

\section{HAL Id: hal-01917959 \\ https://hal.science/hal-01917959}

Submitted on 20 Nov 2019

HAL is a multi-disciplinary open access archive for the deposit and dissemination of scientific research documents, whether they are published or not. The documents may come from teaching and research institutions in France or abroad, or from public or private research centers.
L'archive ouverte pluridisciplinaire HAL, est destinée au dépôt et à la diffusion de documents scientifiques de niveau recherche, publiés ou non, émanant des établissements d'enseignement et de recherche français ou étrangers, des laboratoires publics ou privés. 


\title{
A simple and efficient approach towards photo-sensitive bio- based aliphatic polycarbonate materials
}

\author{
Pierre-Luc Durand,${ }^{\dagger}$ Antoine Brège,${ }^{\dagger}$ Guillaume Chollet, ${ }^{\ddagger}$ Etienne Grau,${ }^{\dagger}$ Henri Cramail ${ }^{\dagger *}$ \\ ${ }^{\dagger}$ Laboratoire de Chimie des Polymères Organiques, UMR 5629, CNRS, Université de Bordeaux, Bordeaux \\ INP/ENSCBP, 16 avenue Pey Berland, 336oo, Pessac, France \\ ‡ ITERG, F-336oo, Pessac, France
}

\begin{abstract}
Fatty acids were used as precursors for the synthesis of photo-sensitive polycarbonate materials. In order to avoid multi-step reactions, a simple and straightforward methodology toward the synthesis of photo-sensitive monomers has been developed. Hence, a fatty acid-based cyclic carbonate bearing an unsaturation was synthesized and subsequently polymerized in a controlled manner $(\mathrm{D}=1, \mathrm{O} 7)$ by organo-catalyzed ring-opening polymerization (ROP). A thio-cinnamate derivative was then readily synthesized via a one-pot reaction and grafted onto the polycarbonate backbone by thiol-ene reaction. The content of photo-responsive cinnamoyl moiety grafted on the polycarbonate was tunable with the reaction time. Such functionalized polycarbonates could be cross-linked (by UV irradiation at $365 \mathrm{~nm}$ ) and de-cross-linked (irradi-

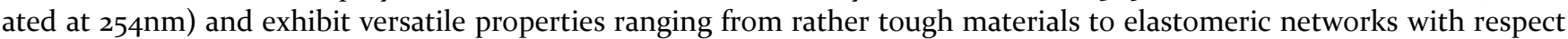
to the content of the photo-sensitive cinnamoyl moiety grafted on the polymer.
\end{abstract}

Aliphatic polycarbonates are well known for their specific features such as low $\mathrm{T}_{\mathrm{g}}$, resistance towards hydrolysis, biocompatibility and biodegradability. ${ }^{1}$ Their synthesis can be achieved via different routes but such polymers are mainly synthesized through ring-opening polymerization (ROP) of cyclic carbonate monomers. ${ }^{2}$ Under suitable conditions, the polymer chain length, dispersity and microstructure as well as the nature of end-groups can be controlled. The advantage of designing functional polycarbonates over the traditional PTMC stems from the modulation of their physico-chemical properties for specific needs, thereby broadening and improving their performance characteristics. Functional polycarbonates can be synthesized either upon direct polymerization of functional monomer or upon chemical modification postpolymerization.3,4 Moreover, because of environmental concerns and also in view of searching novel functionalities, the use of building blocks from renewable resources such as vegetable oils is of great interest. 5 In this purpose and adapted from the work of Venkataraman and coll., ${ }^{6}$ fatty acid-based cyclic carbonates were synthesized as precursors of original aliphatic bio-based polycarbonates.

In addition, polycarbonate networks exhibiting elastomeric properties are desirable thanks to a large number of applications in the biomedical area, especially in the emerging field of soft-tissue engineering or drug delivery. ${ }^{7-12}$ Thus, several research groups have investigated various cross-linking methods affording polycarbonate materials. ${ }^{13-17}$ However, the main drawback of such crosslinked materials is their inability to be reshaped or recycled. As a consequence, new self-healing materials involv- ing reversible cross-linking reactions have been developed. $^{18-21}$ Such materials could be of interest in many fields such as protective coatings, biomedical applications, piping and electronics. ${ }^{19}$

Among all stimuli that can be employed to activate a reversible transformation, light is one of the most used. ${ }^{22,23}$ In the midst of photosensitive moieties, the photo-reactive cinnamate group dimerization, occurring through the $[2+2]$ photochemical cyclo-addition reaction, was implemented for polymerization reactions and for cross-linking purposes. ${ }^{24}$ Using the photo-sensitive cinnamate group, the reversibility of the cross-linking was, for instance, exploited for the synthesis of self-healing polymers $^{25-27}$ and tunable shape-memory materials. ${ }^{28}$ However, a challenge in the field of self-healing polymers is their ease of synthesis. The photo-sensitive moieties are mainly brought through copolymerization of the functional monomer, the latter needing several synthetic steps. ${ }^{24-26}$

Herein, a simple and efficient post-functionalization method involving a thiol-ene coupling is developed towards photo-sensitive aliphatic polycarbonate networks. After synthesizing a bio-based aliphatic polycarbonate bearing pendant unsaturations, several cinnamatecontaining polycarbonates were easily prepared and reversibly cross-linked through UV irradiation. The influence of the cinnamate content on the network properties was also studied. 


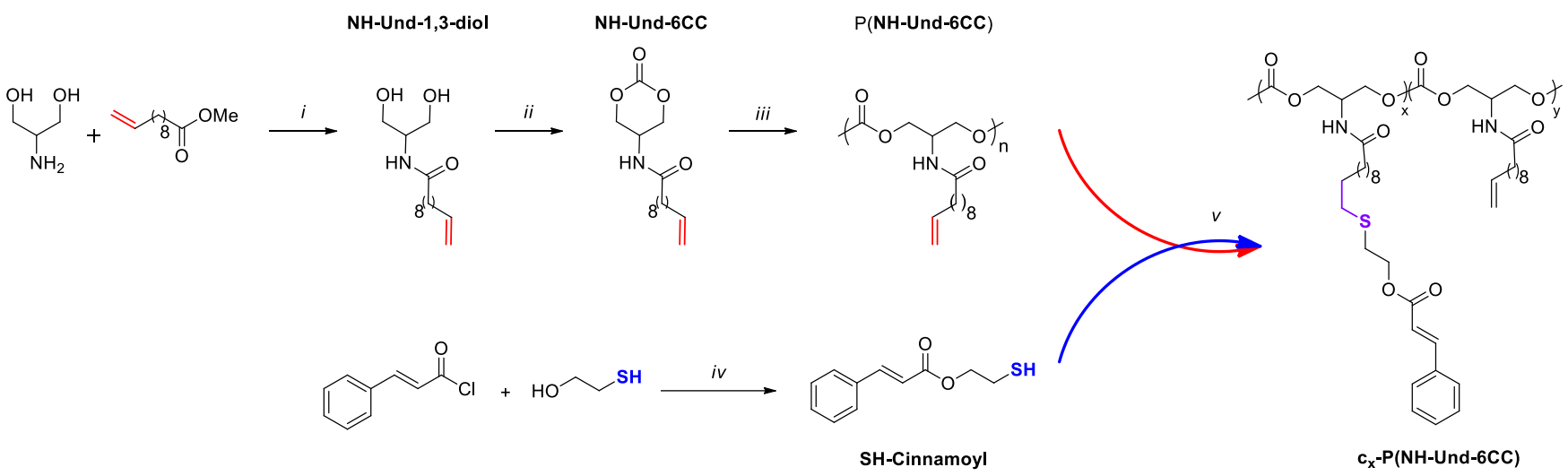

$i$ : TBD, $80^{\circ} \mathrm{C}, 7 \mathrm{~h}$; ii: ethyl chloroformate, triethylamine, THF, RT, overnight; iii: DBU/TUS, BnOH, DCM, RT, $4 \mathrm{~h}$; iv: toluene, reflux, $2 \mathrm{~h} ; v: \mathrm{v}_{70}, \mathrm{DCM}, 40^{\circ} \mathrm{C}$.

The fatty-acid based cyclic carbonate was obtained in two steps. First is the formation of the amide functionalized NH-Und-1,3-diol by coupling the methyl undecenoate and 2-amino-1,3-propanediol. This amidation is performed in bulk at $80^{\circ} \mathrm{C}$, under nitrogen to remove the methanol by-product, in the presence of 1,5,7triazabicyclo[4.4.o]dec-5-ene (TBD) as an organo-catalyst (Yield: 70\%., see Figs. S1-S4). The second step is the intramolecular cyclization giving the corresponding 6membered ring cyclic carbonate $\mathbf{N H - U n d - 6 C C}$ by using ethylchloroformate in THF in the presence of triethylamine as a base (Yield: 55\%., see Figs. $\mathrm{S}_{5}$-S8).

The polymerization of NH-Und-6CC was carried out in $\operatorname{DCM}\left([\mathrm{M}]_{\mathrm{o}}=2.0 \mathrm{M}\right)$ at room temperature with benzyl alcohol $(\mathrm{BnOH})$ as initiator and $[\mathrm{M}]_{\mathrm{o}} /[\mathrm{BnOH}]_{\mathrm{o}}=50$ (Erreur! Source du renvoi introuvable.). DBU was chosen as catalyst associated with the Schreiner thiourea (TUS) as co-catalyst with a ratio of $[\mathrm{M}]_{\mathrm{o}} /[\mathrm{BnOH}]_{\mathrm{o}} /[\mathrm{DBU}]_{\mathrm{o}} /[\mathrm{TUS}]_{\mathrm{o}}=50 / 1 / 1 / 1 . \mathrm{P}(\mathrm{NH}-$ Und-6CC $)$ was successfully obtained with yield up to $90 \%(\mathrm{DP}=50$; $Đ=1.07$, see Fig S9).

The cinnamate-SH moiety was first synthesized through the direct and simple reaction of cinnamic acid chloride with the 2-mercaptoethanol as illustrated in Erreur! Source du renvoi introuvable.. This reaction was performed in stoichiometric conditions with complete conversion and very high (yield: 95\%, see Figs. S10-S13). The next step towards the design of photo-responsive polycarbonate material is the grafting of Cinnamoyl-SH on $\mathrm{P}(\mathrm{NH}-$ Und-6CC). As above-mentioned, the thiol-ene coupling reaction was used to link these two entities. Nevertheless, since Cinnamoyl-SH is sensitive to UV irradiation, a radical initiator which decomposes thermally $\left(V_{70}\right)$ was used to initiate the thiol-ene reaction as depicted in Erreur ! Source du renvoi introuvable..

Syntheses of polycarbonates bearing different amount of pendant cinnamate moieties were carried out (Table 1). The cinnamate content was controlled by the reaction time, see Fig. S15. As expected, an increase of the polymer molar mass values associated to a decrease of the $T_{g}\left(23^{\circ} \mathrm{C}\right.$ to $-20^{\circ} \mathrm{C}$ ) was observed with the cinnamoyl content grafted on the polymer, see Fig. S16. Such a decrease is ex- plained by the flexibility introduced by the sulphur atom to the polymer chains.

Polycarbonate networks were obtained by UV crosslinking using the reactivity of the cinnamate moieties. With UV light at $\lambda=365 \mathrm{~nm}$, the cinnamate group switches from the trans to the cis conformation. When two cis cinnamate groups react together, they undergo a $[2+2]$ cyclo-addition reaction leading to the formation of a cyclobutane ring (Erreur! Source du renvoi introuvable.). This reaction was used to cross-link all cinnamate-functionalized $\mathrm{c}_{\mathrm{x}} \mathrm{P}(\mathrm{NH}-\mathrm{Und}-\mathbf{6 C C})$.

The curing kinetics was studied using UV-vis spectrophotometry by monitoring the absorption maximum at 280 $\mathrm{nm}$, which relates to the double bonds adjacent to carbonyl group of the cinnamate functionality (Figure 1-(a)). As seen in the UV-vis spectrum, a decrease in intensity of the peaks at $280 \mathrm{~nm}$ was observed within $6 \mathrm{~h}$, meaning that almost $100 \%$ of the cinnamate groups have undergone the $[2+2]$ cyclo-addition reaction. The fast initial absorbance decrease is characteristic of the polymer cross-linking through irradiation because the concentration of cinnamate groups is higher in the initial stages. As the cross-linking increases, concentration and mobility of the chains decreases leading to a plateau.

Scheme 2. Photo-reversible cross-linking of a cinnamate containing bio-based polycarbonate
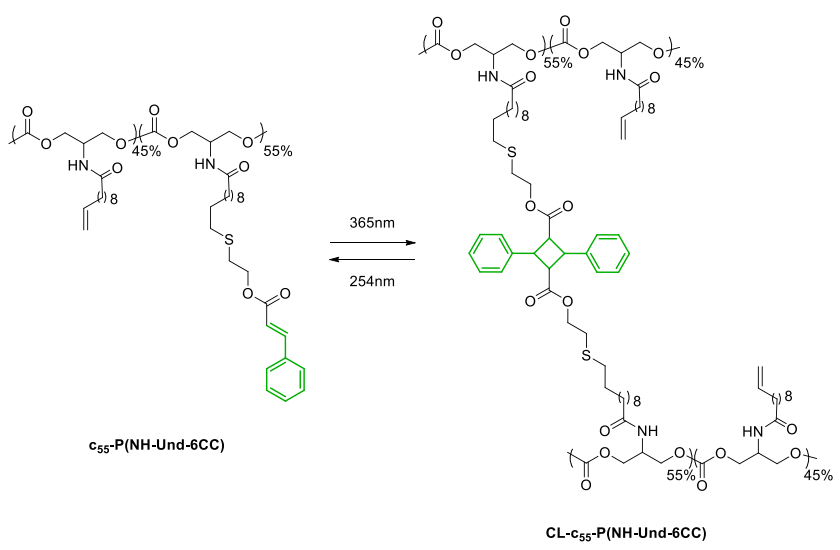
Subsequently, upon exposing the cross-linked polycarbonate to $254 \mathrm{~nm}$ light irradiation, the de-cross-linking of the polycarbonate material occurs.

Table 1. Molecular characterization of cinnamate-containing polycarbonates

\begin{tabular}{|c|c|c|c|c|c|}
\hline Polymer & $\begin{array}{l}\text { Reaction time } \\
\text { (min) }\end{array}$ & $\begin{array}{c}\text { Cinnamoyl content } \\
\text { (mol. } \%)\end{array}$ & $\mathrm{M}_{\mathrm{n}} \mathrm{b}\left(\mathrm{g} \cdot \mathrm{mol}^{-1}\right)$ & {$[\mathbf{Đ}]^{\mathbf{b}}$} & $\mathrm{T}_{\mathrm{g}}\left({ }^{\circ} \mathrm{C}\right)^{\mathrm{c}}$ \\
\hline P(NH-Und-6CC) & o & o & 5700 & 1.07 & 23 \\
\hline $\mathrm{c}_{10}-\mathrm{P}(\mathrm{NH}-\mathrm{Und}-6 \mathrm{CC})$ & 0.5 & 10 & 5800 & 1.10 & 11 \\
\hline$c_{30}-P(N H-U n d-6 C C)$ & 2 & 30 & 5900 & 1.18 & 5 \\
\hline$c_{55}-\mathrm{P}(\mathrm{NH}-$ Und-6CC) & 6 & 55 & 6500 & 1.25 & -1 \\
\hline $\mathrm{c}_{70}-\mathrm{P}(\mathrm{NH}-$ Und-6CC) & 15 & 70 & 8500 & 1.29 & -12 \\
\hline $\mathrm{c}_{100}-\mathrm{P}(\mathrm{NH}-$ Und-6CC) & 30 & 100 & 9400 & 1.31 & -20 \\
\hline
\end{tabular}

a: Determined by ${ }^{1} \mathrm{H}$ NMR; ${ }^{b}$ : Determined by SEC in THF (PS Std); ${ }^{c}$ : Determined by DSC at $10^{\circ} \mathrm{C} \cdot \mathrm{min}^{-1}$ from the second cycle

The de-cross-linking reaction is relatively fast but the absorbance doesn't reach its former value before crosslinking indicating that the de-cross-linking is not complete probably due to the poor power of the UV lamp at this wavelength. In order to have a total decross-linking, an appropriate UV lamp must be used, allowing a proper irradiation below $300 \mathrm{~nm}$. Nevertheless, Figure 1 demonstrates the reversible feature of the photo-mediated crosslinked polycarbonate.
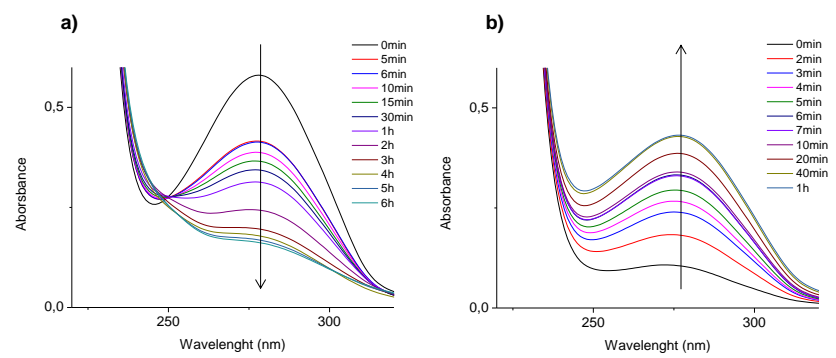

Figure 1. a) Cross-linking kinetic under $365 \mathrm{~nm}$ and b) decross-linking kinetic under $254 \mathrm{~nm}$ in solution (DCM)

All functional polycarbonates were cross-linked by the [2+2] photochemical cyclo-addition of cinnamoyl units to form cross-linked polycarbonates (CL- $\mathrm{C}_{\mathrm{x}}-\mathrm{P}(\mathrm{NH}-\mathrm{Und}-$ 6CC)). First, to evaluate the network cross-linking density, swelling tests have been performed. It can be noted from Table 2 that very low gel content $(7 \%)$ was observed when only $10 \mathrm{~mol} \%$ of cinnamoyl units were grafted to $\mathrm{P}(\mathbf{N H}-$ Und-6CC). The poor photoreactivity in a solidstate coated film explains this low gel content. However, the gel content increases significantly when the pendent cinammoyl content increases in the polymer to almost reach $100 \%$. At the same time, the swelling ratio decreases when the cross-linking increases. This feature shows that the cross-linking density can be controlled by adjusting the polycarbonate cinnamoyl content. After crosslinking, thermal and mechanical chacterizations of these networks were investigated by differential scanning calorimetry (DSC, Figs. S16-17), thermogravimetry (TGA, Fig. S18), tensile tests experiments (Fig. S19) and dynamic mechanical analysis (Fig. S20-21). All the results are summarized in Table 2 . Such cross-linked materials demonstrated slight increase in $\mathrm{T}_{\mathrm{g}}$ with an increase of crosslinking density. More interestingly, mechanical properties of the networks strongly depend on the cross-linking density. Indeed, $\mathrm{CL}-\mathrm{C}_{10}-\mathrm{P}\left(\mathrm{NH}-\right.$ Und-6CC) and $\mathrm{CL}_{-} \mathrm{C}_{30^{-}}$ $\mathrm{P}(\mathbf{N H}-$ Und-6CC) are transparent and flexible materials at room temperature as shown in Figure 2. However, when high cinnamoyl content was used, the materials became more rigid. Consequently, the fully functionalized crosslinked polymer was very brittle. In addition, the influence of the cross-linking density on the polycarbonate mechanical properties can be clearly seen. $\mathrm{CL}_{-} \mathrm{C}_{10}-\mathrm{P}(\mathrm{NH}-$ Und-6CC) displays very low Young modulus calculated from the initial slope of the stress-strain curve (1.3 MPa) while $\mathrm{CL}-\mathrm{C}_{100}-\mathrm{P}(\mathbf{N H}-$ Und-6CC) exhibits a Young modulus 1 ooo times higher. In between these values, the higher the cross-linking density, the higher the Young modulus. Max stress at break values follows the same trend. However, the elongation at break follows opposite tendency. Therefore, the mechanical properties of the polycarbonate networks are significantly affected by the cinnamoyl content grafted on $\mathrm{P}(\mathrm{NH}-$ Und-6CC).

The elastic modulus measured above $\mathrm{T}_{\mathrm{g}}$ by DMA exhibited an increase up to 9.5 MPa for the most highly crosslinked polycarbonate. Moreover, in agreement with the results obtained by DSC, we observe that the $\mathrm{T}_{\text {alpha }}$ increases with the increase of the cross-linking density.

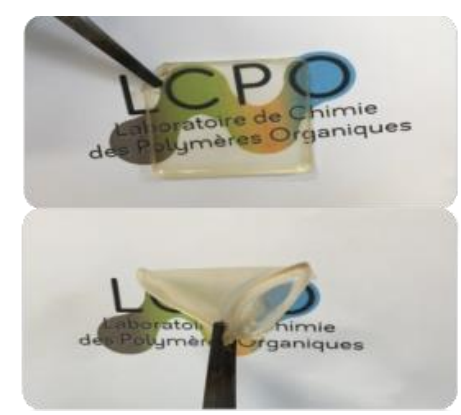

Figure 2. Pictures of flexible $\mathrm{CL}-\mathrm{c}_{30}-\mathrm{P}(\mathrm{NH}-\mathrm{Und}-6 \mathrm{CC})$ 
In conclusion, several cinnamate-containing polycarbonates were synthesized via the simple and controllable thiol-ene reaction between $\mathrm{P}(\mathrm{NH}-\mathrm{Und}-\mathbf{6 C C})$ and thiofunctionalized cinnamate moiety. Photo-reversible polycarbonate networks were prepared thanks to the photoinduced $[2+2]$ cyclo-addition reaction between two cinnamoyl groups.

Table 2. Summary of mechanical properties exhibiting by photo-mediated cross-linked polycarbonates

\begin{tabular}{|c|c|c|c|c|c|c|}
\hline Network & $\begin{array}{c}\mathrm{T}_{\mathrm{g}} \text { network } \\
\left({ }^{\circ} \mathrm{C}\right)^{\mathrm{a}}\end{array}$ & $\begin{array}{l}\text { Modulus } \\
(\mathrm{MPa})^{\mathrm{b}}\end{array}$ & $\begin{array}{c}\text { Elongation } \\
\text { at break }(\%)^{\mathbf{b}}\end{array}$ & $\begin{array}{l}\text { Max stress } \\
\left(_{(\mathrm{MPa})^{\mathbf{b}}}\right.\end{array}$ & $\begin{array}{c}\text { Gel content } \\
(\%)\end{array}$ & $\begin{array}{l}\text { Swelling } \\
\text { ratio (\%) }\end{array}$ \\
\hline CL-c $\mathrm{c}_{10}-\mathrm{P}(\mathrm{NH}-\mathrm{Und}-6 \mathrm{CC})$ & 8 & $1.3 \pm 0.5$ & $156 \pm 15$ & $0.5 \pm 0.2$ & 7 & 69 \\
\hline CL- $\mathrm{c}_{30}-\mathrm{P}(\mathrm{NH}-\mathrm{Und}-6 \mathrm{CC})$ & 11 & $39 \pm 7$ & $49 \pm 8$ & $2.4 \pm 0.7$ & 64 & 153 \\
\hline $\mathrm{CL}^{-\mathrm{c}_{55}}-\mathrm{P}(\mathrm{NH}-\mathrm{Und}-6 \mathrm{CC})$ & 13 & $110 \pm 21$ & $15 \pm 4$ & $6 \pm 1$ & 85 & 62 \\
\hline CL-c $\mathrm{C}_{70}-\mathrm{P}(\mathrm{NH}-\mathrm{Und}-6 \mathrm{CC})$ & 24 & $622 \pm 50$ & $6 \pm 3$ & $29 \pm 5$ & 99 & 48 \\
\hline CL-C ${ }_{100}-\mathrm{P}(\mathrm{NH}-\mathrm{Und}-6 \mathrm{CC})$ & 17 & $1266 \pm 55$ & $3 \pm 1$ & $35 \pm 5$ & 95 & 57 \\
\hline
\end{tabular}

a: Determined by DSC at $10^{\circ} \mathrm{C} \cdot \mathrm{min}^{-1}$ from the second cycle; b: Calculated from tensile tests

Among the advantages of this synthetic approach, is the use of the cinnamate moiety to control the cross-linking density in time and space via UV light without requiring any initiators or chemical cross-linkers that can remain in the final polymer. Thanks to the reversibility of the crosslinking reaction (proved by UV-Vis spectrophotometry), such materials could be reshaped or recycled with appropriate UV lamp.

\section{ASSIOCATED CONTENT}

Supporting Information. Figures, experimental procedures, full characterization data and copies of relevant NMR (functional monomers and polymers).

\section{AUTHOR INFORMATION}

\section{Corresponding Author}

*cramail@enscbp.fr

\section{ACKNOWLEDGMENTS}

This work was performed, in partnership with the SAS PIVERT, within the frame of the French Institute for the Energy Transition (Institut pour la Transition Energétique ITE) P.I.V.E.R.T. (www.institut-pivert.com) selected as an Investment for the Future ("Investissements d'Avenir"). This work was supported, as part of the Investments for the Future, by the French Government under the reference ANRoo1-o1. The authors thank Equipex Xyloforest ANR-10-EQPX16. The financial support from the CPER CAMPUSB project funded by the French state and the Région Nouvelle Aquitaine is gratefully acknowledged

\section{REFERENCES}

(1) Artham, T.; Doble, M. Biodegradation of aliphatic and aromatic polycarbonates. Macromol. Biosci. 2008, 8 (1), 14-24.

(2) Rokicki, G.; Parzuchowski, P. G. G. ROP of cyclic carbonates and ROP of macrocycles; Elsevier, 2012; Vol. 4.

(3) Tempelaar, S.; Mespouille, L.; Coulembier, O.; Dubois, P.; Dove, A. P. Synthesis and post-polymerisation modifications of aliphatic poly(carbonate)s prepared by ring-opening polymerisation. Chem. Soc. Rev. 2013, 42 (3), 1312-1336.

(4) Y. Dai, Y. ; X. Zhang, X. ; Xia, F. Click Chemistry in Functional Aliphatic Polycarbonates. Macromol. Rapid Commun. 2017, 38, 1700357

(5) Montero De Espinosa, L.; Meier, M. A. R.; De Espinosa, L.; Meier, M. A. R. Plant oils: The perfect renewable resource for polymer science?! .Eur. Polym. J. 2011, 47 (5), 837-852.

(6) Venkataraman, S.; Veronica, N.; Voo, Z. X.; Hedrick, J. L.; Yang, Y.-Y. Y. 2-Amino-1,3-propane diols: a versatile platform for the synthesis of aliphatic cyclic carbonate monomers. Polym. Chem. 2013, 4 (10), 2945-2948.

(7) Martina, M.; Hutmacher, D. W. Biodegradable polymers applied in tissue engineering research: a review. Polym. Int. 2007, 56, 145-157.

(8) Amsden, B. Curable, biodegradable elastomers: emerging biomaterials for drug delivery and tissue engineering. Soft Matter 2007, 3 (11), 1335-1348.

(9) Pêgo, A. P.; Poot, A. A.; Grijpma, D. W.; Feijen, J. Biodegradable elastomeric scaffolds for soft tissue engineering. $J$. Control. Release 2003, 87 (1-3), 69-79.

(10) Place, E. S.; George, J. H.; Williams, C. K.; Stevens, M. M. Synthetic polymer scaffolds for tissue engineering. Chem. Soc. Rev. 2009, 38 (4), 1139-1151.

(11) Fukushima, K. Poly(trimethylene carbonate)-based polymers engineered for biodegradable functional biomaterials. Biomater. Sci. 2016, 4, 9-24.

(12) Feng, J.; Zhuo, R. X.; Zhang, X. Z. Construction of functional aliphatic polycarbonates for biomedical applications. Prog. Polym. Sci. 2012, 37 (2), 211-236.

(13) Pascual, A.; Tan, J. P. K.; Yuen, A.; Chan, J. M. W.; Coady, D. J.; Mecerreyes, D.; Hedrick, J. L.; Yang, Y. Y.; Sardon, H. Broad-Spectrum Antimicrobial Polycarbonate Hydrogels with Fast Degradability. Biomacromolecules 2015, 16 (4), 1169-1178.

(14) Yuen, A. Y.; Lopez-Martinez, E.; Gomez-Bengoa, E.; Cortajarena, A. L.; Aguirresarobe, R. H.; Bossion, A.; Mecerreyes, D.; Hedrick, J. L.; Yang, Y. Y.; Sardon, H. Preparation of Biodegradable Cationic Polycarbonates and Hydrogels through the Direct Polymerization of Quaternized Cyclic Carbonates. ACS Biomater. Sci. Eng. 2017, 3 (8), 1567-1575.

(15) Martín, C.; Kleij, A. W. Terpolymers Derived from Limonene Oxide and Carbon Dioxide: Access to Cross-Linked 
Polycarbonates with Improved Thermal Properties. Macromolecules 2016, 49 (17), 6285-6295.

(16) Stevens, D. M.; Tempelaar, S.; Dove, A. P.; Harth, E. Nanosponge Formation from Organocatalytically Synthesized Poly(carbonate) Copolymers. ACS Macro Lett. 2012, 1, 915-918.

(17) Schüller-Ravoo, S.; Feijen, J.; Grijpma, D. W. Preparation of Flexible and Elastic Poly(trimethylene carbonate) Structures by Stereolithography. Macromol. Biosci. 2011, 11 (12), 16621671.

(18) Guimard, N. K.; Oehlenschlaeger, K. K.; Zhou, J.; Hilf, S.; Schmidt, F. G.; Barner-Kowollik, C. Current Trends in the Field of Self-Healing Materials. Macromol. Chem. Phys. 2012, 213 (2), 131-143.

(19) Binder, W. H. Self-Healing Polymers: From Principles to Applications; Wiley-CVH, 2013.

(2o) Billiet, S.; Hillewaere, X. K. D.; Teixeira, R. F. A.; Du Prez, F. E. Chemistry of crosslinking processes for self-healing polymers. Macromol. Rapid Commun. 2013, 34 (4), 290-309.

(21) Bekas, D. G.; Tsirka, K.; Baltzis, D.; Paipetis, A. S. Selfhealing materials: A review of advances in materials, evaluation, characterization and monitoring techniques. Compos. Part B Eng. 2016, 87, 92-119.

(22) Habault, D.; Zhang, H.; Zhao, Y. Light-triggered selfhealing and shape-memory polymers. Chem. Soc. Rev. 2013, 42 (17), 7244-7456.

(23) Ercole, F.; Davis, T. P.; Evans, R. A. Photo-responsive systems and biomaterials: photochromic polymers, lighttriggered self-assembly, surface modification, fluorescence modulation and beyond. Polym. Chem. 2010, 1 (1), 37-54.

(24) Hu, X.; Chen, X.; Cheng, H.; Jing, X. Cinnamatefunctionalized poly(ester-carbonate): Synthesis and its UV irradiation-induced photo-crosslinking. J. Polym. Sci. Part A Polym. Chem. 2009, 47, 161-169.

(25) Tunc, D.; Le Coz, C.; Alexandre, M.; Desbois, P.; Lecomte, P.; Carlotti, S. Reversible Cross-Linking of Aliphatic Polyamides Bearing Thermo- and Photoresponsive Cinnamoyl Moieties. Macromolecules 2014, 47 (23), 8247-8254.

(26) Chung, C.; Roh, Y.; Cho, S.; Kim, J. Crack Healing in Polymeric Materials via Photochemical [2+2] Cycloaddition. Chem. Mater 2004, 16 (12), 3982-3984.

(27) Froimowicz, P.; Klinger, D.; Landfester, K. Photoreactive Nanoparticles as Nanometric Building Blocks for the Generation of Self-Healing Hydrogel Thin Films. Chem. - A Eur. J. 2011, 17 (44), 12465-12475.

(28) Garle, A.; Kong, S.; Ojha, U.; Budhlall, B. M. Thermoresponsive Semicrystalline Poly( $\varepsilon$-caprolactone) Networks: Exploiting Cross-linking with Cinnamoyl Moieties to Design Polymers with Tunable Shape Memory. ACS Appl. Mater. Interfaces 2012, 4 (2), 645-657. 


\section{Supporting Information}

\section{A simple and efficient approach towards photo-sensitive bio-based}

\section{aliphatic polycarbonate materials}

Pierre-Luc Durand,$^{\dagger}$ Antoine Brège ${ }^{\dagger}$ Guillaume Chollet, ${ }^{\dagger}$ Etienne Grau ${ }^{\dagger}$ and Henri Cramail ${ }^{\dagger^{*}}$

${ }^{\dagger}$ Laboratoire de Chimie des Polymères Organiques, UMR 5629, CNRS, Université de Bordeaux, Bordeaux INP/ENSCBP, 16 avenue Pey Berland, 33600, Pessac, France

$\ddagger$ ITERG, F-33600, Pessac, France

* Correspondence to Henri Cramail (cramail@enscbp.fr)

\section{Table of Contents:}

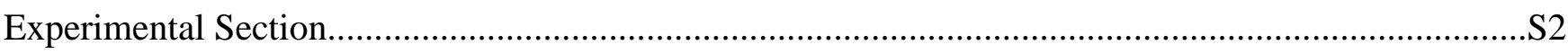

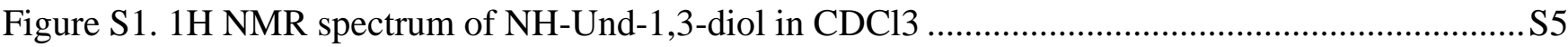

Figure S2. 13C NMR spectrum of NH-Und-1,3-diol in CDCl3 _................................................ 6

Figure S3. 1H-1H COSY spectrum of NH-Und-1,3-diol in CDCl3 ............................................S7

Figure S4. 1H-13C HSQC spectrum of NH-Und-1,3-diol in CDCl3 .............................................S

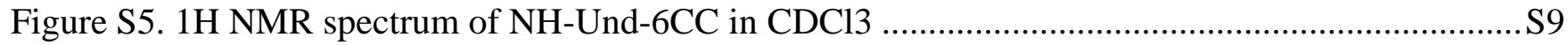

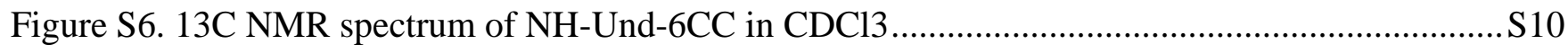

Figure S7. 1H-1H COSY spectrum of NH-Und-6CC in CDCl3 ................................................. 11

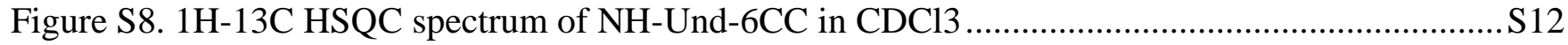

Figure S9. 1H NMR spectrum of P(NH-Und-6CC) in CDCl3 ...............................................S13

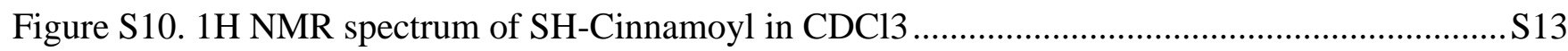

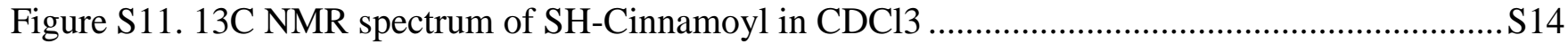

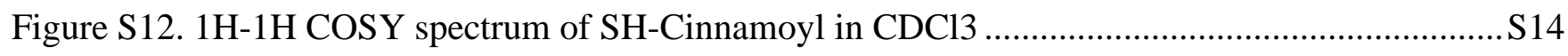

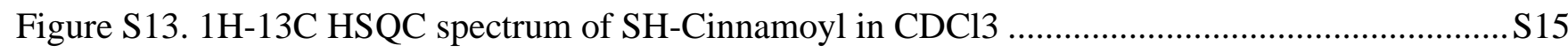

Figure S14. 1H NMR spectrum of cinnamoyl-containing polycarbonate in THF. Example with 30

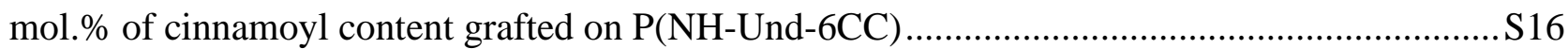

Figure S15. SEC traces of cinnamoyl-containing polymers in THF (Polystyrene standards) ..............S16

Figure S16. Second heating scans of DSC measurement of cinnamoyl-containing polycarbonates .....S17

Figure S17. Second heating scans of DSC measurement of cross-linked cinnamoyl-containing

polycarbonates

Figure S18: TGA analysis of cross-linked cinnamoyl-containinig polycarbonates 
Figure S19. Stress-strain curves at room temperature of the polycarbonate networks prepared with the

[2+2] photochemical cyclo-addition of pendent cinnamoyl units S20

Figure S20. Thermo-mechanical experiments showing the tensile storage modulus ( $\left.\mathrm{E}^{\prime}\right)$ measured using

DMA at an oscillation frequency of $1 \mathrm{~Hz}$ S21

\section{Experimental Section}

\section{Materials.}

Ethyl chloroformate (97\%), 2-mercaptoethanol (98\%), benzyl alcohol (BnOH), benzoic acid, 1,5,7-triazabicyclodec-5ene (TBD, $98 \%)$, sodium sulfate $\left(\mathrm{Na}_{2} \mathrm{SO}_{4}\right)$, magnesium sulfate $\left(\mathrm{MgSO}_{4}\right)$, 1,8-diazabicyclo[5.4.0]undec-7-ene (DBU) and 1,3-bis[3,5-bis(trifluoromethyl)phenyl]thiourea (Schreiner TU, >98.0\%) were obtained from Sigma-Aldrich. Triethylamine $\left(\mathrm{Et}_{3} \mathrm{~N}, 99 \%\right)$ was purchased from Alfa Aesar. Methyl 10-undecenoate was obtained from Nu-Chek Prep, Inc. Cinnamoyl chloride (predominantly trans, 98\%) was purchased from TCI Europe. 2,2'-Azobis(4-methoxy-2,4dimethylvaleronitrile) (V70) was obtained from Wako.

ITERG kindly provided NH-Und-1,3-diol.

All products and solvents (reagent grade) were used as received except otherwise mentioned. The solvents were of reagent grade quality and were purified wherever necessary according to the methods reported in the literature. Flash chromatography was performed on a Grace Reveleris apparatus, employing silica cartridges from Grace. Cyclohexane: ethyl acetate and dichloromethane: methanol gradients were used as eluents depending on the products. The detection was performed through ELSD and UV detectors at $254 \mathrm{~nm}$ and $280 \mathrm{~nm}$.

\section{Characterization.}

${ }^{1} \mathrm{H}$ and ${ }^{13} \mathrm{C}$-NMR spectra were recorded on Bruker Avance 400 spectrometer $(400.20 \mathrm{MHz}$ or $400.33 \mathrm{MHz}$ and 100.63 $\mathrm{MHz}$ for ${ }^{1} \mathrm{H}$ and ${ }^{13} \mathrm{C}$, respectively) by using $\mathrm{CDCl}_{3}$ as a solvent at room temperature, except otherwise mentioned. Two-dimensional analyses such as ${ }^{1} \mathrm{H}-{ }^{1} \mathrm{H}$ COSY (COrrelation SpectroscopY), ${ }^{1} \mathrm{H}^{-13} \mathrm{C}$ HSQC (Heteronuclear Single Quantum Spectroscopy) and were also performed. Size Exclusion Chromatography (SEC) analyses were performed in THF $\left(25^{\circ} \mathrm{C}\right)$ on a PL GPC50 and with four TSK columns: HXL-L (guard column), G4000HXL (particles of $5 \mathrm{~mm}$, pore size of 200A, and exclusion limit of $400000 \mathrm{~g} / \mathrm{mol}$ ), G3000HXL (particles of $5 \mathrm{~mm}$, pore size of 75A, and exclusion limit of $60000 \mathrm{~g} / \mathrm{mol}$ ), G2000HXL (particles of $5 \mathrm{~mm}$, pore size of $20 \mathrm{~A}$, and exclusion limit of $10000 \mathrm{~g} / \mathrm{mol}$ ) at an elution rate of $1 \mathrm{~mL} / \mathrm{min}$. The elution times of the filtered samples were monitored using $\mathrm{UV}$ and RI detectors and SEC were calibrated using polystyrene standards. Differential scanning calorimetry (DSC) thermograms were measured using a DSC Q100 apparatus from TA instruments. For each sample, two cycles from -80 to $100^{\circ} \mathrm{C}$ at $10^{\circ} \mathrm{C} \cdot \mathrm{min}^{-1}$ were performed and then the glass transition and melting temperatures were calculated from the second heating run. Thermogravimetric (TGA) analyses were performed on TGA-Q50 system from TA instruments at a heating rate of 10 ${ }^{\circ} \mathrm{C} \cdot \mathrm{min}^{-1}$ under nitrogen atmosphere from room temperature to $600^{\circ} \mathrm{C}$. Dynamic mechanical analyses (DMA) were performed on RSA 3 (TA instrument). The sample temperature was modulated from $-50{ }^{\circ} \mathrm{C}$ to $150{ }^{\circ} \mathrm{C}$, depending on the sample at a heating rate of $4{ }^{\circ} \mathrm{C} \cdot \mathrm{min}^{-1}$. The measurements were performed in a tension mode at a frequency of $1 \mathrm{~Hz}$, an initial static force of $0.1 \mathrm{~N}$ and a strain sweep of $0.04 \%$. Photo-crosslinking were performed using a UV lamp 
HAMAMATSU equipped with a LC8 lamp (full power of $4000 \mathrm{~mW} . \mathrm{cm}^{-1}$ ) and an A9616-03 filter transmitting in the range $280-400 \mathrm{~nm}$, avoiding the heating of the mixture reaction. The samples were placed at a distance of $9 \mathrm{~cm}$ of the UV lamp

\section{Synthesis of NH-Und-1,3-diol}

Methyl 10-undecenoate (1 equiv.), was mixed with 2-amino-1,3-propanediol (1.3 equiv.). TBD (0.05 equiv.) was added to the reaction mixture and heated up at $80^{\circ} \mathrm{C}$ under a nitrogen flow to remove methanol formed. The reaction mixture was heated for $3 \mathrm{~h}$. Depending on the matrix, the reaction mixture might become solid indicating the end of the reaction. The product is then extracted with $\mathrm{CHCl}_{3}$ and washed 3 times with water. Brine is added in case of emulsion. The organic phase was dried over $\mathrm{Na}_{2} \mathrm{SO}_{4}$ and the solvent was removed under vacuum to yield NH-Und-1,3-diol. The diol was obtained as white crystals. Yield: $70 \% .{ }^{1} \mathrm{H}$ NMR (400 MHz, $\left.\mathrm{CDCl}_{3}\right) \delta(\mathrm{ppm}): 6.22(\mathrm{~s}, \mathrm{NH}), 5.81(\mathrm{~m}, 1 \mathrm{H}), 4.93$ $(\mathrm{m}, 2 \mathrm{H}), 3.96(\mathrm{~m}, 1 \mathrm{H}), 3.84(\mathrm{~m}, 2 \mathrm{H}), 3.78(\mathrm{~m}, 2 \mathrm{H}), 2.72(2 \mathrm{OH}), 2.24(\mathrm{t}, 2 \mathrm{H}), 2.04(\mathrm{q}, 2 \mathrm{H}), 1.65(\mathrm{~m}, 2 \mathrm{H}), 1.38-1.25(\mathrm{~m}$, $10 \mathrm{H}) .{ }^{13} \mathrm{C}$ NMR (100 MHz, $\left.\mathrm{CDCl}_{3}\right) \delta(\mathrm{ppm}): 174.39\left(\mathrm{CH}_{2}-\mathrm{CO}-\mathrm{NH}\right), 139.33\left(\mathrm{CH}_{2}=\mathrm{CH}-\mathrm{CH}_{2}\right), 114.31\left(\mathrm{CH}_{2}=\mathrm{CH}-\mathrm{CH}_{2}\right)$, $63.76\left(\mathrm{CH}-\left(\mathrm{CH}_{2}-\mathrm{OH}\right)_{2}\right), 52.49\left(\mathrm{CH}-\left(\mathrm{CH}_{2}-\mathrm{OH}\right)_{2}\right), 36.94\left(\mathrm{CH}_{2}-\mathrm{CO}-\mathrm{NH}\right), 33.92\left(\mathrm{CH}_{2}=\mathrm{CH}-\mathrm{CH}_{2}\right), 29.44-29.02\left(\mathrm{CH}_{2}\right)$, $25.84\left(\mathrm{CH}_{2}-\mathrm{CH}_{2}-\mathrm{CO}-\mathrm{NH}\right)$.

\section{Synthesis of NH-Und-6CC}

In a $500 \mathrm{~mL}$ round bottom flask at $0^{\circ} \mathrm{C}$ equipped with magnetic stirrer, NH-Und-1,3-diol (1.0 equiv.) and ethyl chloroformate (4.0 equiv.) were dissolved in $300 \mathrm{~mL}$ THF. To the cold reaction mixture, triethylamine (4.0 equiv.) was added dropwise over $10 \mathrm{~min}$. The reaction was allowed to proceed in ice-cold conditions for about 1 hour and then allowed to proceed at room temperature overnight. The precipitated solids were filtered off and the volatiles were removed to result in crude product, which was subjected to flash column chromatography, using a gradient of DCM (100 $\%)$ to DCM (95\%) and methanol (5\%) solvent mixture, followed by the removal of volatiles to result in white solid NH-Und-6CC as the functional monomer. Yield: 55\%. $\left.{ }^{1} \mathrm{H} \mathrm{NMR} \mathrm{(400} \mathrm{MHz,} \mathrm{CDCl}_{3}\right) \delta(\mathrm{ppm}): 7.63(\mathrm{~s}, \mathrm{NH}), 5.76(\mathrm{~m}$, 1H), $4.93(\mathrm{~m}, 2 \mathrm{H}), 4.54-4.40(\mathrm{~m}, 5 \mathrm{H}), 2.22(\mathrm{t}, 2 \mathrm{H}), 1.99(\mathrm{q}, 2 \mathrm{H}), 1.60(\mathrm{t}, 2 \mathrm{H}), 1.25(\mathrm{~m}, 10 \mathrm{H}) .{ }^{13} \mathrm{C} \mathrm{NMR}(100 \mathrm{MHz}$, $\left.\mathrm{CDCl}_{3}\right) \delta(\mathrm{ppm}): 174.33\left(\mathrm{CH}_{2}-\mathrm{CO}-\mathrm{NH}\right), 148.66(\mathrm{OCOO}), 139.19\left(\mathrm{CH}_{2}=\mathrm{CH}-\mathrm{CH}_{2}\right), 114.21\left(\mathrm{CH}_{2}=\mathrm{CH}-\mathrm{CH}_{2}\right), 71.45(\mathrm{CH}-$ $\left.\left(\mathrm{CH}_{2}-\mathrm{OCOO}\right)_{2}\right), 40.94\left(\mathrm{CH}-\left(\mathrm{CH}_{2}-\mathrm{OCOO}\right)_{2}\right), 36.14\left(\mathrm{CH}_{2}-\mathrm{CO}-\mathrm{NH}\right), 33.81\left(\mathrm{CH}_{2}=\mathrm{CH}-\mathrm{CH}_{2}\right), 29.34-28.93\left(\mathrm{CH}_{2}\right), 25.57$ $\left(\mathrm{CH}_{2}-\mathrm{CH}_{2}-\mathrm{CO}-\mathrm{NH}\right)$.

\section{Polymerization of NH-Und-6CC}

All polymerizations were performed under inert atmosphere (nitrogen) using standard Schlenk, vacuum line, and glovebox techniques. In a $15 \mathrm{~mL}$ schlenk flask containing a magnetic stirrer, in glove box, NH-Und-6CC (50 equiv.), $\mathrm{BnOH}$ (2.0 equiv.) and Schreiner TU (1.0 equiv.) were dissolved in dry DCM ([NH-Und-6CC] $=2$ mol.L $\mathrm{L}^{-1}$ ). To this solution, DBU (1.0 equiv.) was added to initiate polymerization. The reaction mixture was allowed to stir at room temperature. After $5 \mathrm{~h}$, the reaction was quenched by the addition of benzoic acid (2 equiv.) and purified by precipitation in cold methanol to yield P(NH-Und-6CC). The polymer was obtained as white solid. Yield: $91 \%$. ${ }^{1} \mathrm{H} \mathrm{NMR}(400 \mathrm{MHz}$, $\left.\mathrm{CDCl}_{3}\right) \delta(\mathrm{ppm}): 5.80(\mathrm{~m}, 1 \mathrm{H}), 4.93(\mathrm{~d}, 2 \mathrm{H}), 4.64-3.93(\mathrm{~m}, 5 \mathrm{H}), 2.24(\mathrm{~m}, 2 \mathrm{H}), 2.01(\mathrm{q}, 2 \mathrm{H}), 1.62(\mathrm{~m}, 2 \mathrm{H}), 1.28(\mathrm{~m}$, 10H). SEC (THF, RI): Mn= $5700 \mathrm{~g} \cdot \mathrm{mol}^{-1}, \mathrm{D}=1.07$. 


\section{Synthesis of SH-Cinnamoyl}

In a round-bottom flask equipped with magnetic stirrer, cinnamoyl chloride (20 g, $120 \mathrm{mmol})$ was dissolved in toluene (300 mL). 2-mercaptoethanol (9.3 g, $120 \mathrm{mmol}, 1$ equiv.) was added and the mixture was stirred under reflux for 2 hours. The solvent was removed on rotary evaporator yielding to SH-Cinnamoyl as viscous liquid without further purification. Yield=90\%. ${ }^{1} \mathrm{H}$ NMR $\left(\mathrm{CDCl}_{3}, 400 \mathrm{MHz}\right) \delta(\mathrm{ppm}): 7.73(\mathrm{~d}, 1 \mathrm{H}), 7.53(\mathrm{~m}, 2 \mathrm{H}), 7.38(\mathrm{~m}, 3 \mathrm{H}), 6.47(\mathrm{~d}, 1 \mathrm{H})$, $4.33(\mathrm{t}, 2 \mathrm{H}), 2.82(\mathrm{q}, 2 \mathrm{H}), 1.55$ (t, SH). ${ }^{13} \mathrm{C} \mathrm{NMR}\left(100 \mathrm{MHz}, \mathrm{CDCl}_{3}\right) \delta(\mathrm{ppm}): 167.45\left(\mathrm{CH}-\mathrm{COO}-\mathrm{CH}_{2}\right), 146.56(\mathrm{Ph}-$ $\underline{\mathrm{C}} \mathrm{H}=\mathrm{CH}), 133.19-128.31(\mathrm{Ph}), 118.21(\mathrm{CH}=\underline{\mathrm{CH}}-\mathrm{COO}), 66.95\left(\mathrm{CH}-\mathrm{COO}-\underline{\mathrm{C}} \mathrm{H}_{2}\right), 23.74\left(\mathrm{CH}_{2}-\underline{\mathrm{C}} \mathrm{H}_{2}-\mathrm{SH}\right)$

\section{Grafting of SH-Cinnamoyl on P(NH-Und-6CC)}

In a round-bottom flask equipped with magnetic stirrer, P(NH-Und-6CC) (1 equiv.), SH-Cinnamoyl (3 equiv.) and V70 (1 mol.\%) were dissolved in DCM (1 mol.L-1). The reaction was allowed to proceed at $40^{\circ} \mathrm{C}$ during the appropriate period of time. The solvent was removed to result in $\mathrm{c}_{\mathrm{x}}-\mathrm{P}(\mathbf{N H}-\mathbf{U n d}-\mathbf{6 C C})$ which was purified by dialysis in methanol (1L for $1 \mathrm{~g}$ of polymer, $48 \mathrm{~h}$, and methanol was changed after $24 \mathrm{~h}$ ). Grafting of cinnamoyl moieties were calculated by 1H NMR (Figure S14) according to Erreur ! Source du renvoi introuvable..

$$
\% \text { Cinnamoyl }=\frac{\int H_{11}}{\int H_{7}+\int H_{11}}
$$

Equation 1: Formula used for the calculation of cinnamoyl percentage grafted after the thiol-ene reaction using ${ }^{1} \mathrm{H}$ NMR integrations of characteristic protons $\left(\mathrm{H}_{11}\right.$ and $\left.\mathrm{H}_{7}\right)$ in $\mathrm{CDCl}_{3}$

\section{Photo-cross-linking of $\mathrm{c}_{\mathrm{x}}=\mathrm{P}(\mathrm{NH}-\mathrm{Und}-\mathbf{6 C C})$}

The polymer $\mathrm{c}_{\mathrm{x}}-\mathrm{P}(\mathbf{N H}-\mathbf{U n d}-\mathbf{6 C C})$ was dissolved in chloroform $\left(\mathrm{CHCl}_{3}\right)$ at $1 \mathrm{~g} \cdot \mathrm{mL}^{-1}$ in a vial. After evaporation of the solvent, the films were exposed to UV light at a distance of $9 \mathrm{~cm}$, wavelength $\lambda=365 \mathrm{~nm}$, for $12 \mathrm{~h}$ on each side to form a network structure $\mathrm{CL}-\mathrm{c}_{\mathrm{x}}-\mathrm{P}(\mathbf{N H}-\mathbf{U n d}-\mathbf{6 C C})$ and to ensure uniform curing. 


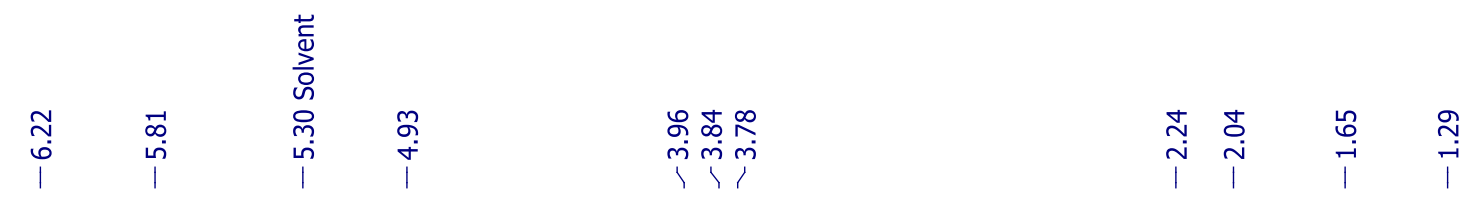

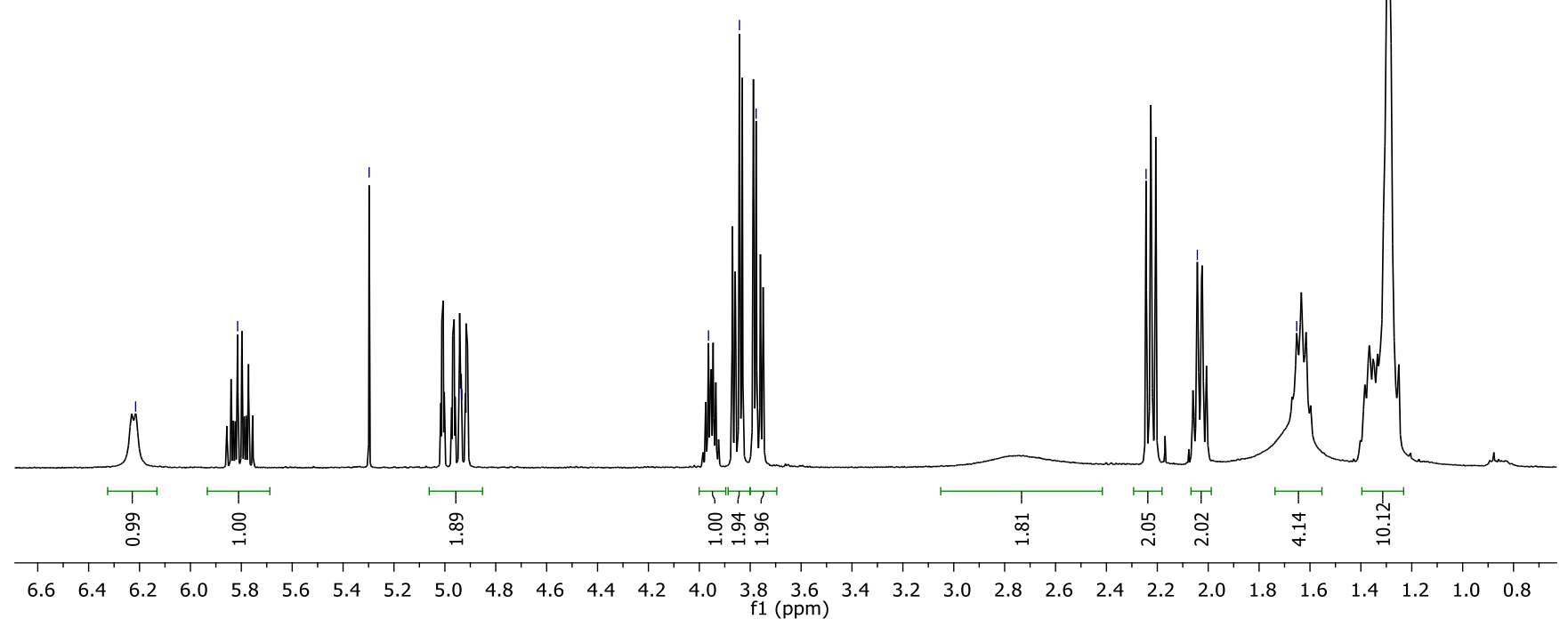

Figure S1. ${ }^{1} \mathrm{H}$ NMR spectrum of NH-Und-1,3-diol in $\mathrm{CDCl}_{3}$ 


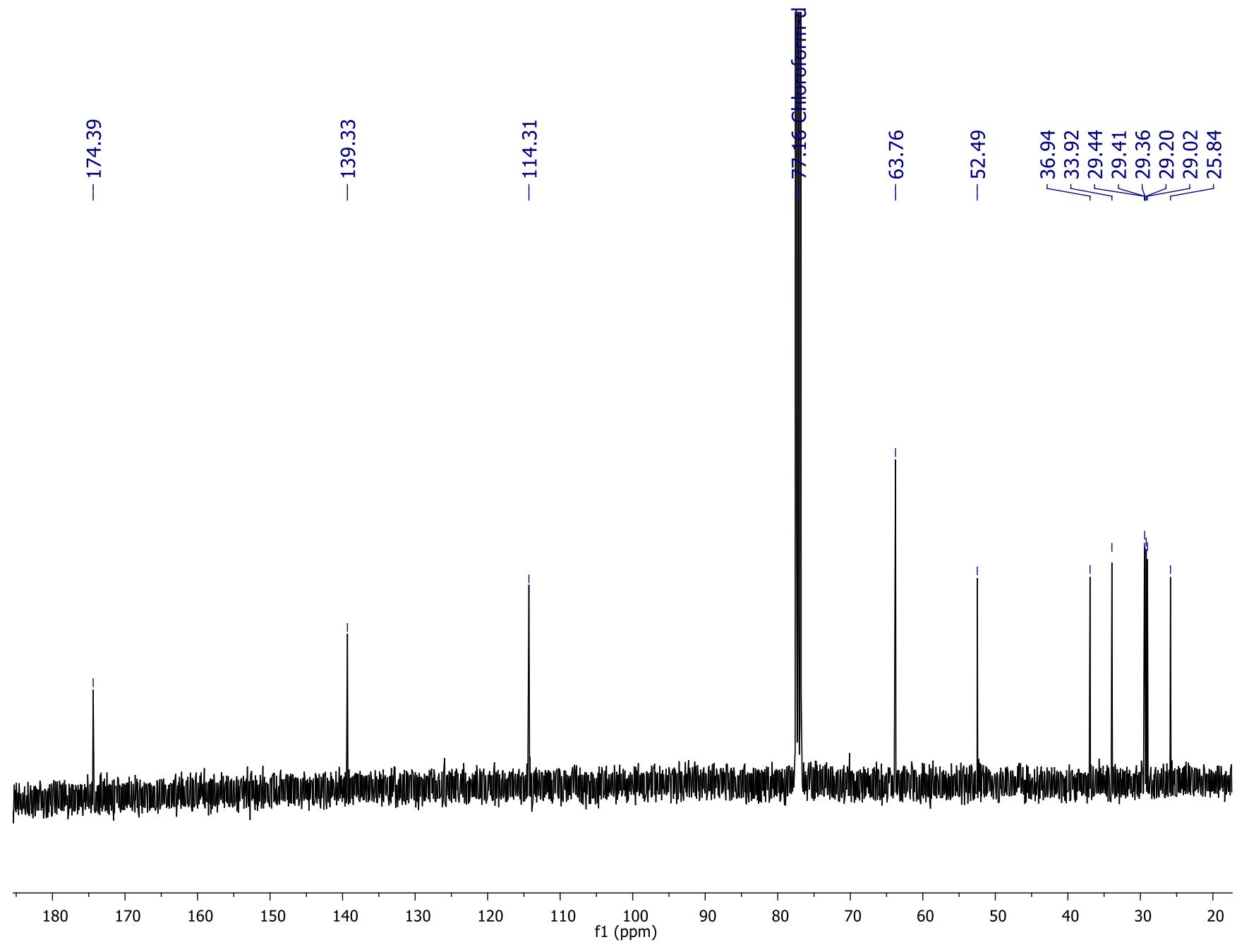

Figure S2. ${ }^{13} \mathrm{C}$ NMR spectrum of NH-Und-1,3-diol in $\mathrm{CDCl}_{3}$ 


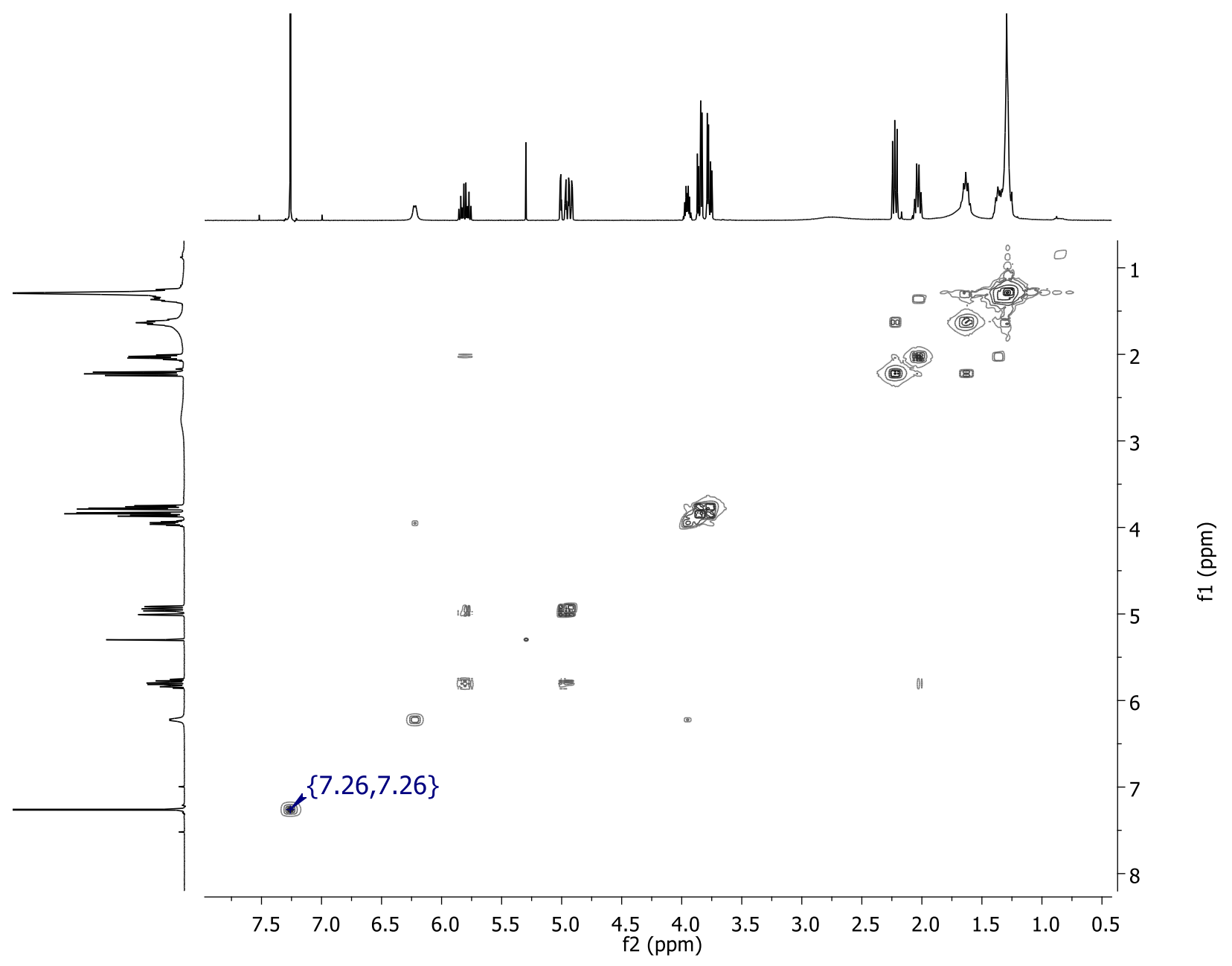

Figure S3. ${ }^{1} \mathrm{H}-{ }^{1} \mathrm{H}$ COSY spectrum of NH-Und-1,3-diol in $\mathrm{CDCl}_{3}$ 


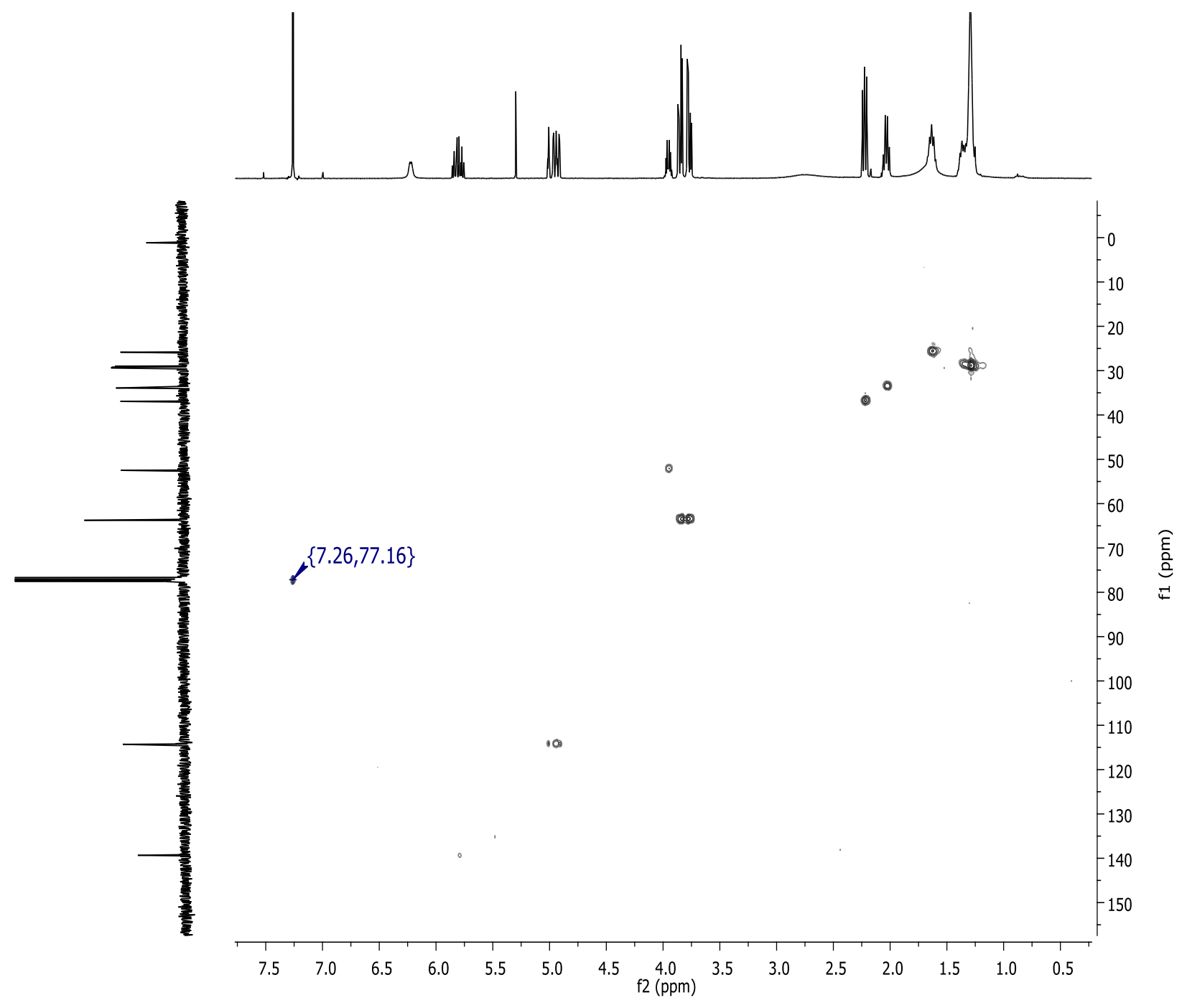

Figure S4. ${ }^{1} \mathrm{H}-{ }^{13} \mathrm{C}$ HSQC spectrum of $\mathbf{N H}-$ Und-1,3-diol in $\mathrm{CDCl}_{3}$ 


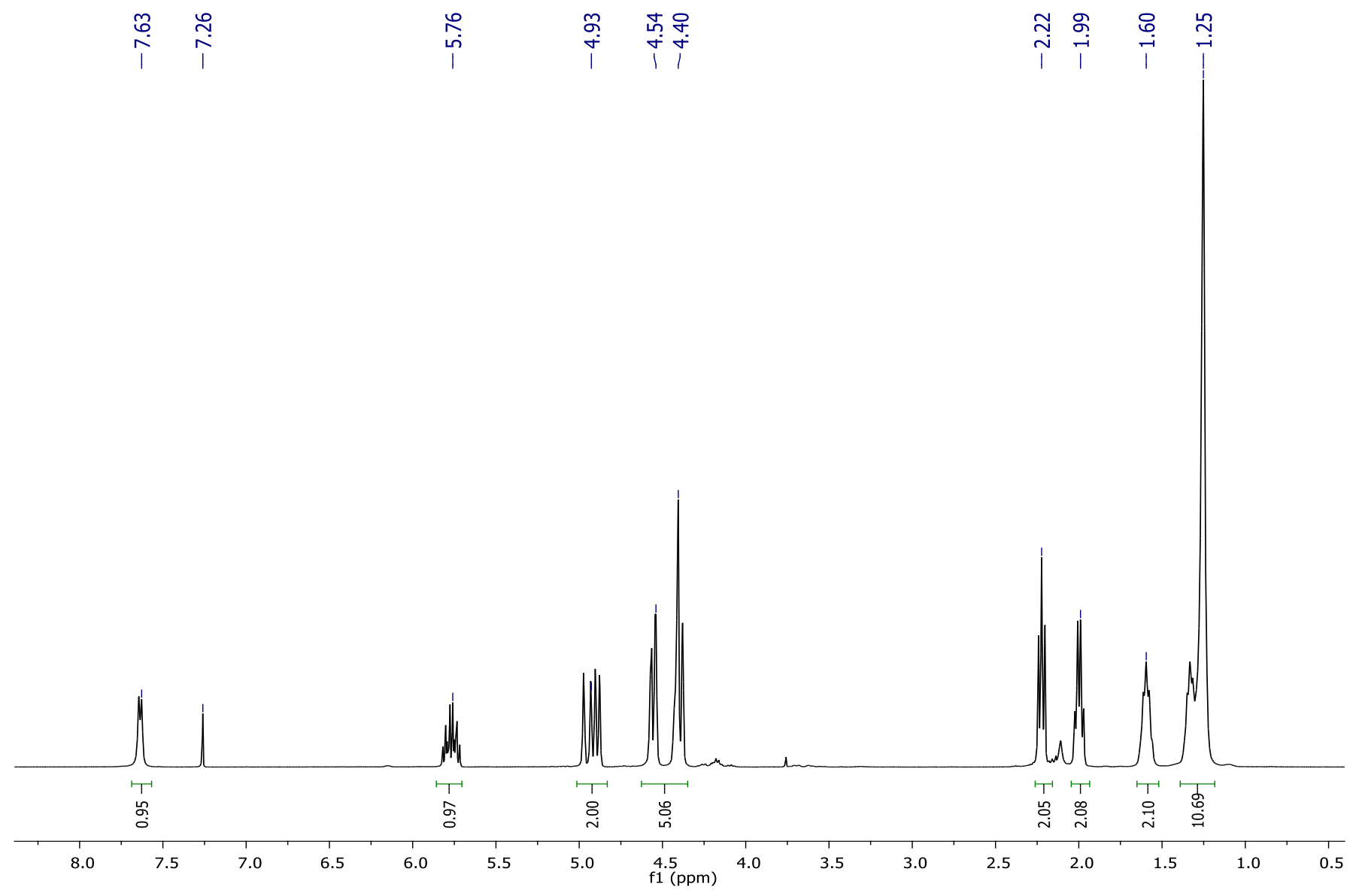

Figure S5. ${ }^{1} \mathrm{H}$ NMR spectrum of $\mathbf{N H}$-Und-6CC in $\mathrm{CDCl}_{3}$ 


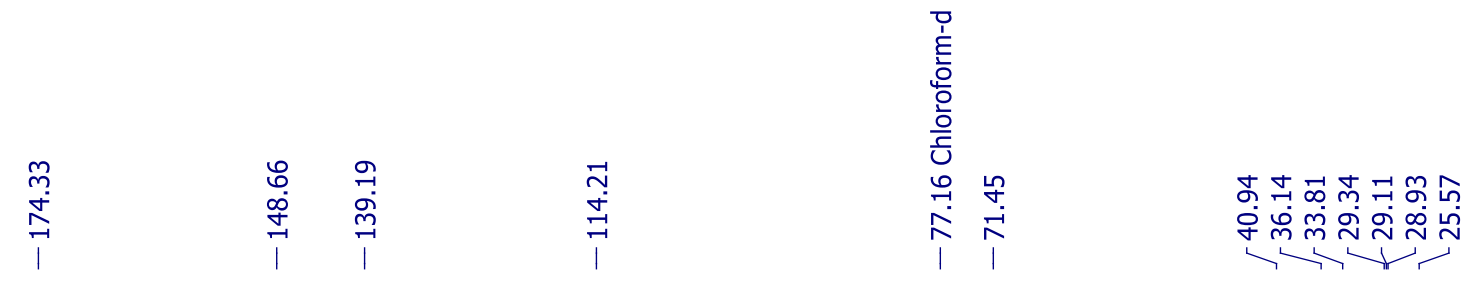
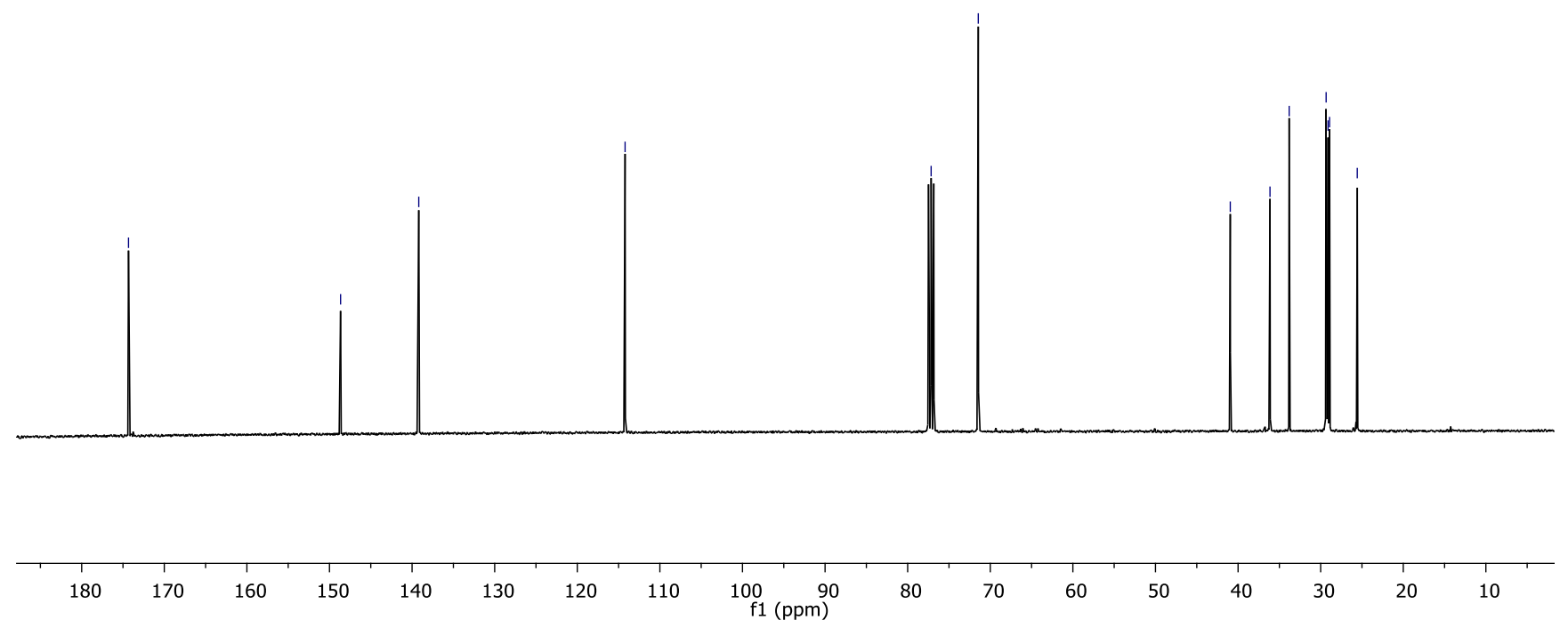

Figure S6. ${ }^{13} \mathrm{C}$ NMR spectrum of NH-Und-6CC in $\mathrm{CDCl}_{3}$ 


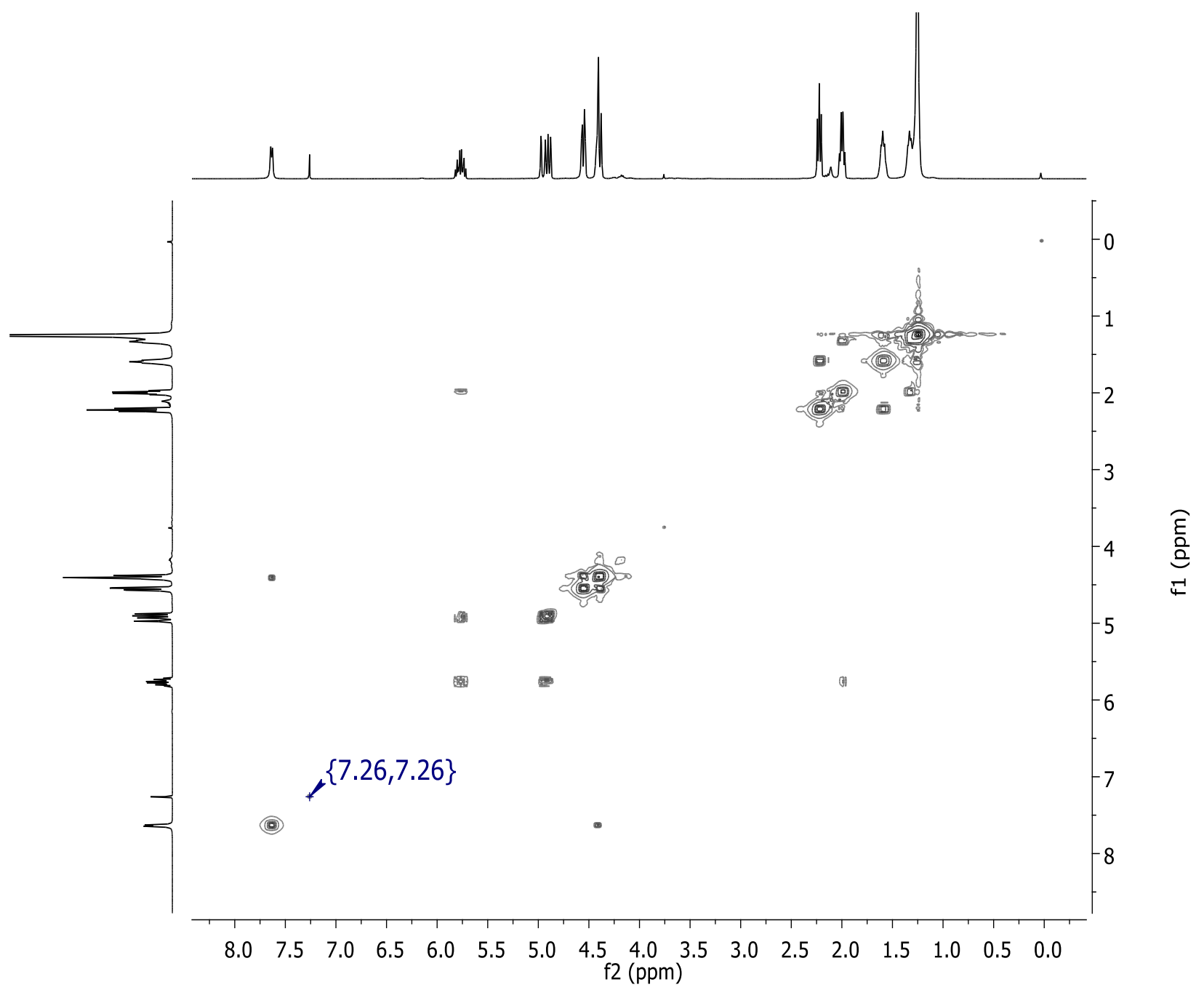

Figure S7. ${ }^{1} \mathrm{H}-{ }^{1} \mathrm{H}$ COSY spectrum of NH-Und-6CC in $\mathrm{CDCl}_{3}$ 


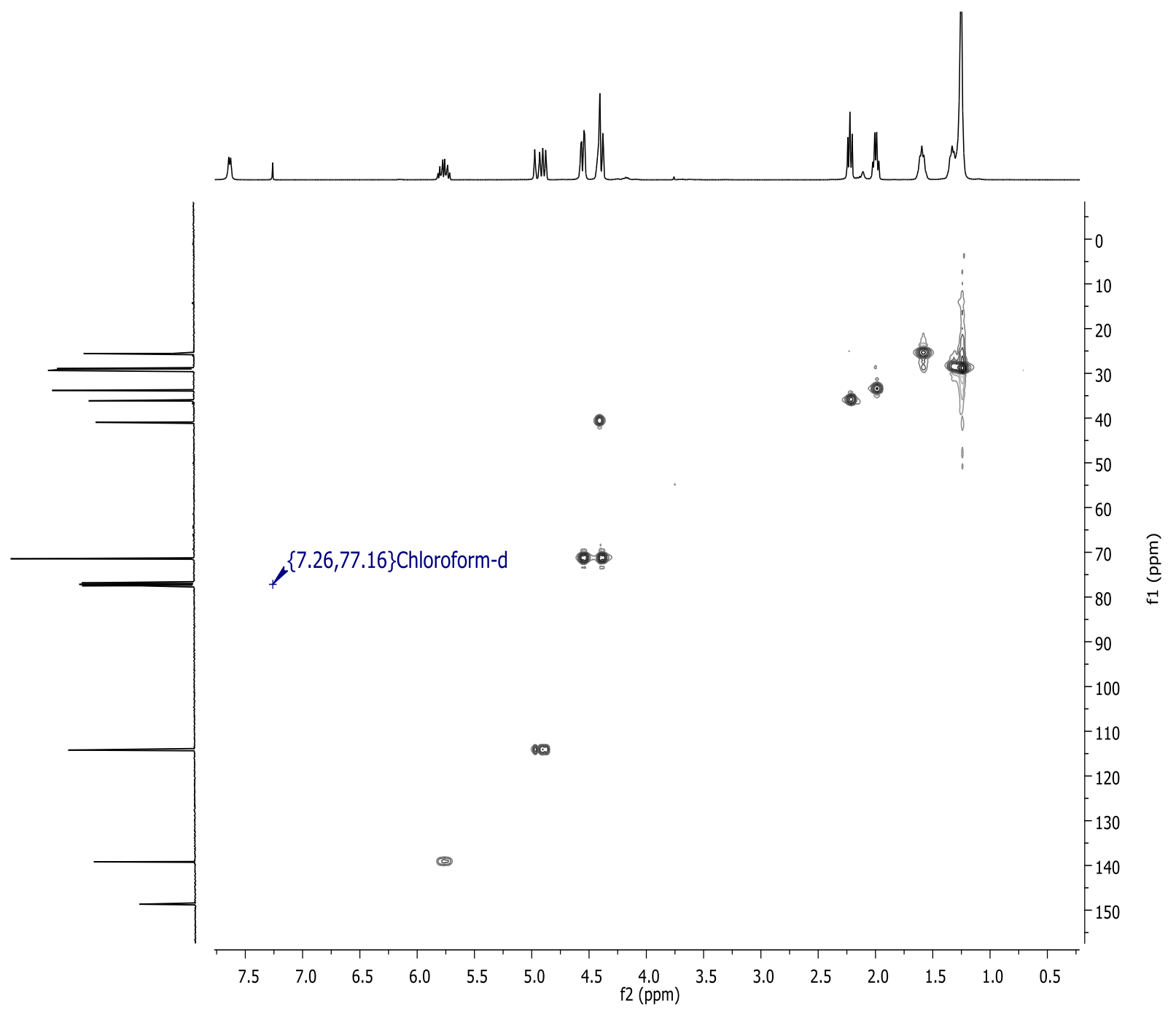

Figure S8. ${ }^{1} \mathrm{H}-{ }^{13} \mathrm{C}$ HSQC spectrum of NH-Und-6CC in $\mathrm{CDCl}_{3}$ 


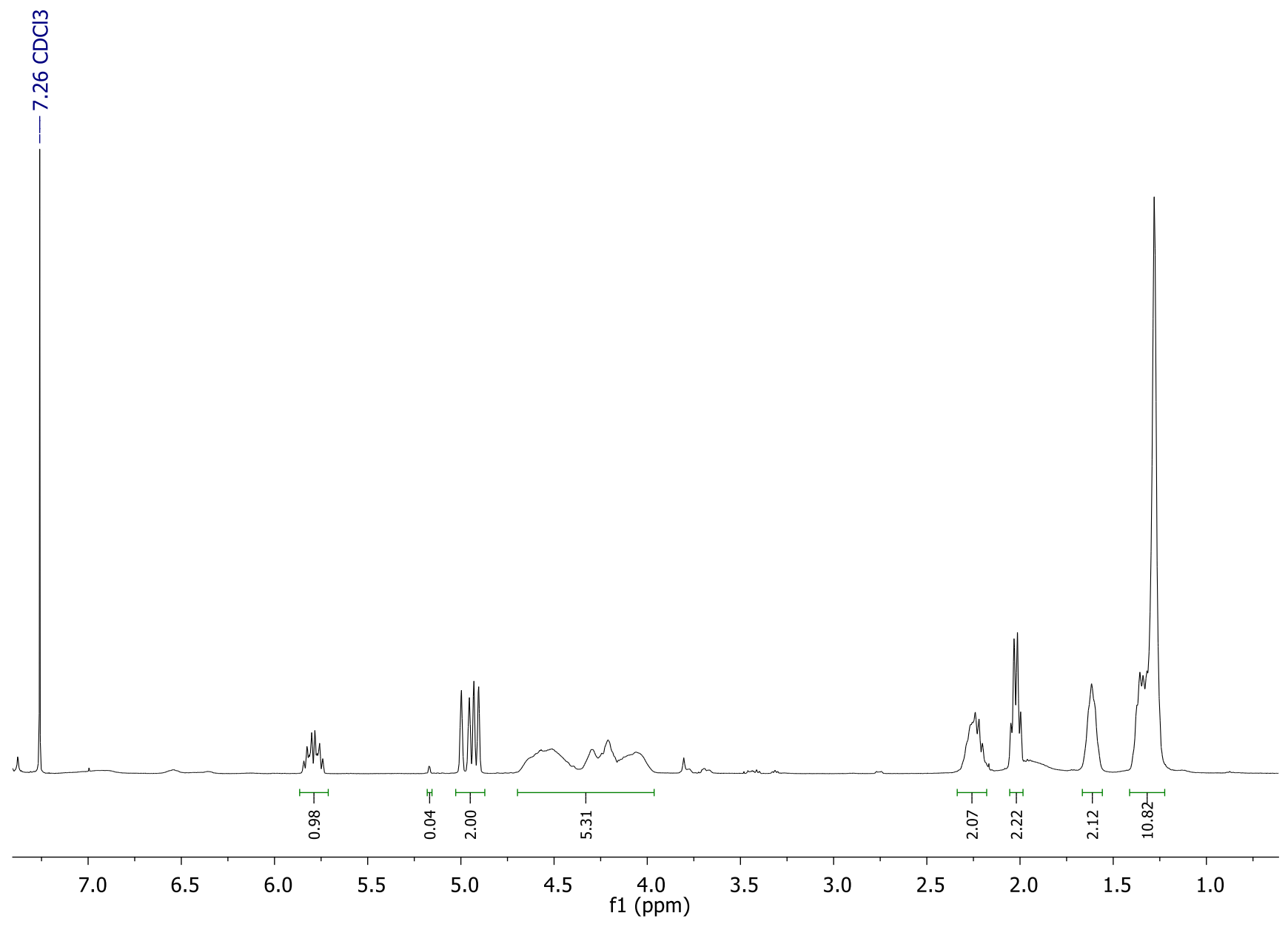

Figure S9. ${ }^{1} \mathrm{H}$ NMR spectrum of $\mathrm{P}(\mathbf{N H}-\mathbf{U n d}-\mathbf{6 C C})$ in $\mathrm{CDCl}_{3}$

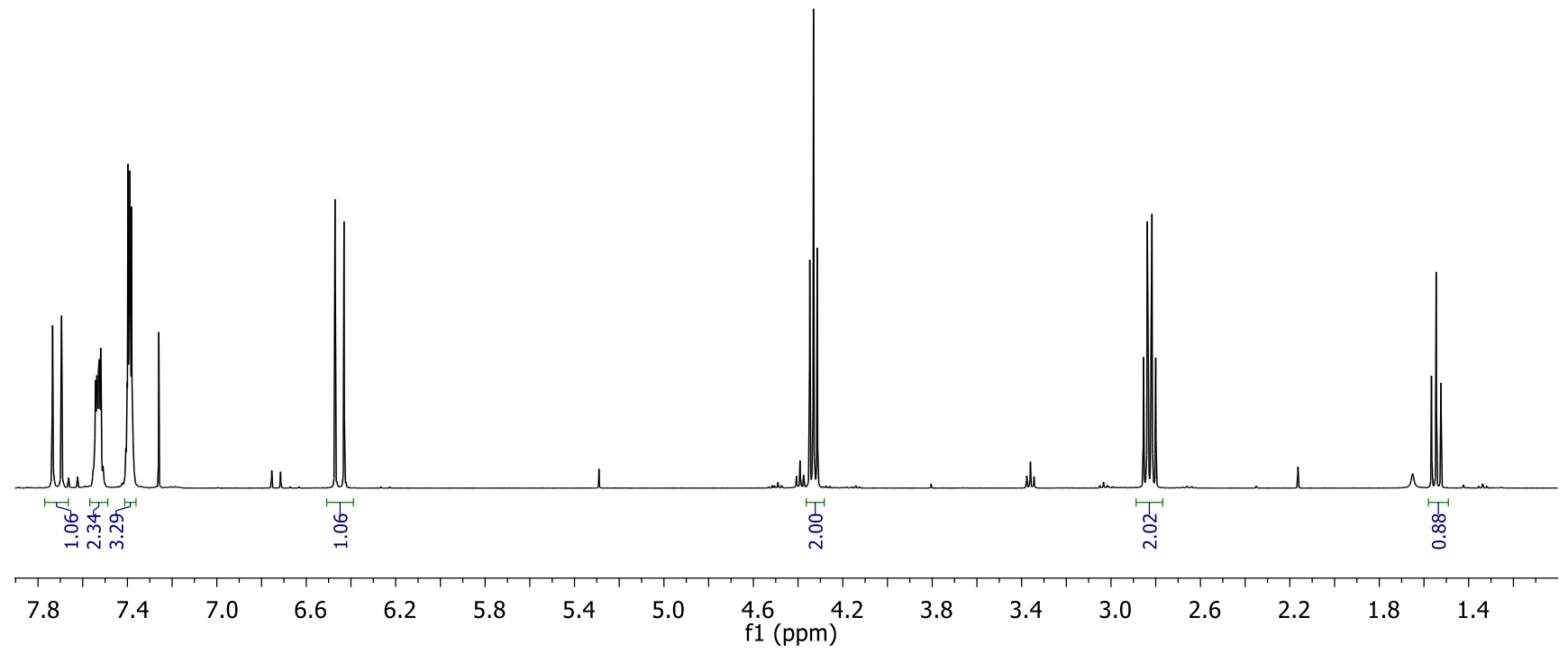

Figure S10. ${ }^{1} \mathrm{H}$ NMR spectrum of SH-Cinnamoyl in $\mathrm{CDCl}_{3}$ 


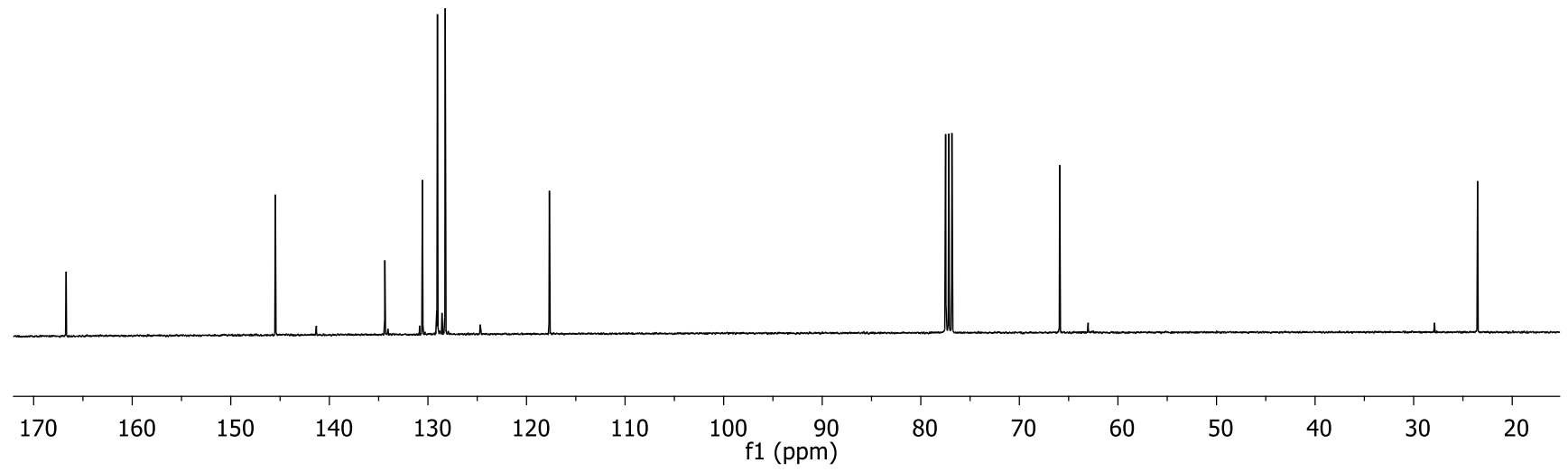

Figure S11. ${ }^{13} \mathrm{C}$ NMR spectrum of SH-Cinnamoyl in $\mathrm{CDCl}_{3}$

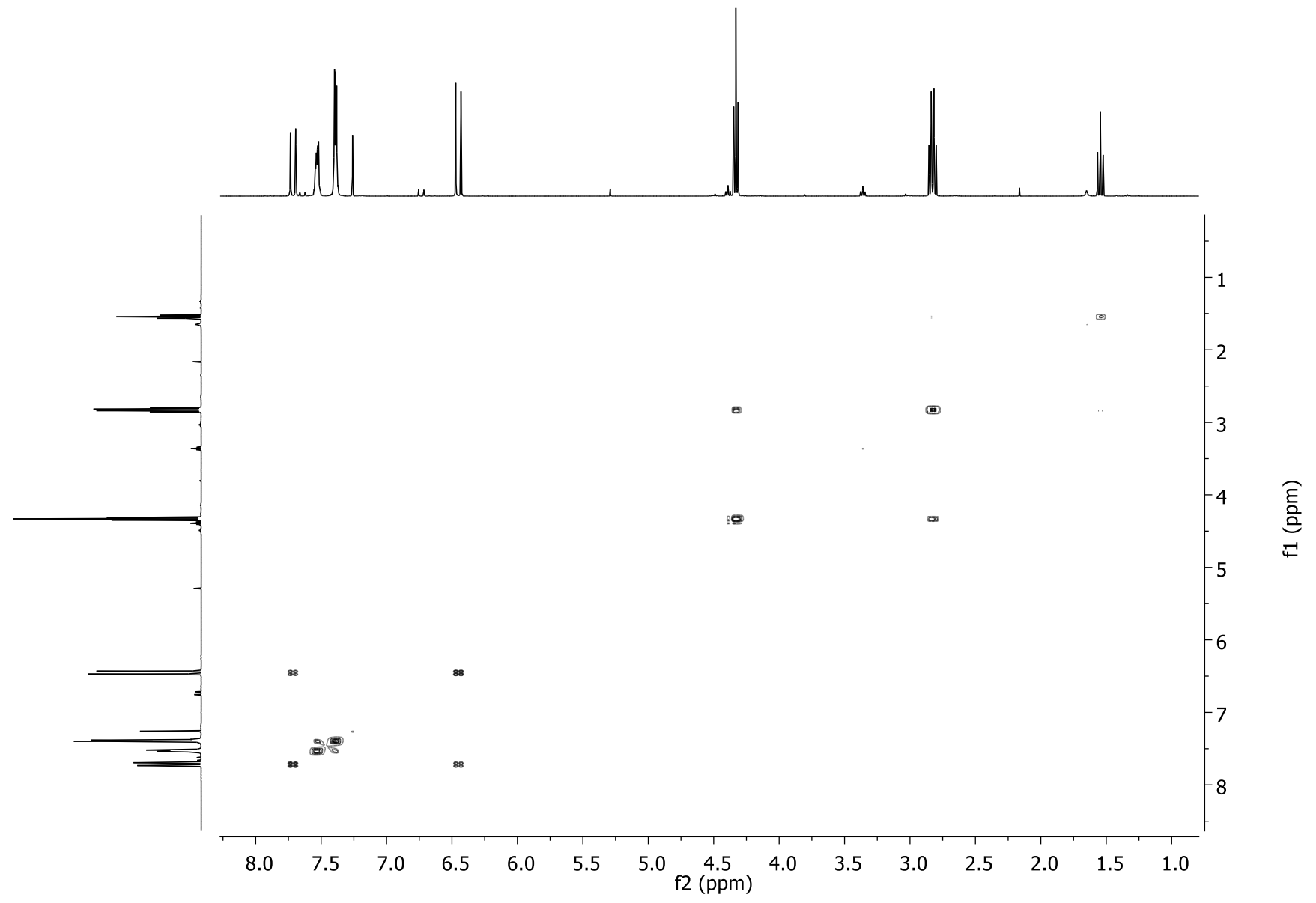

Figure S12. ${ }^{1} \mathrm{H}-{ }^{1} \mathrm{H}$ COSY spectrum of $\mathbf{S H}-$ Cinnamoyl in $\mathrm{CDCl}_{3}$ 


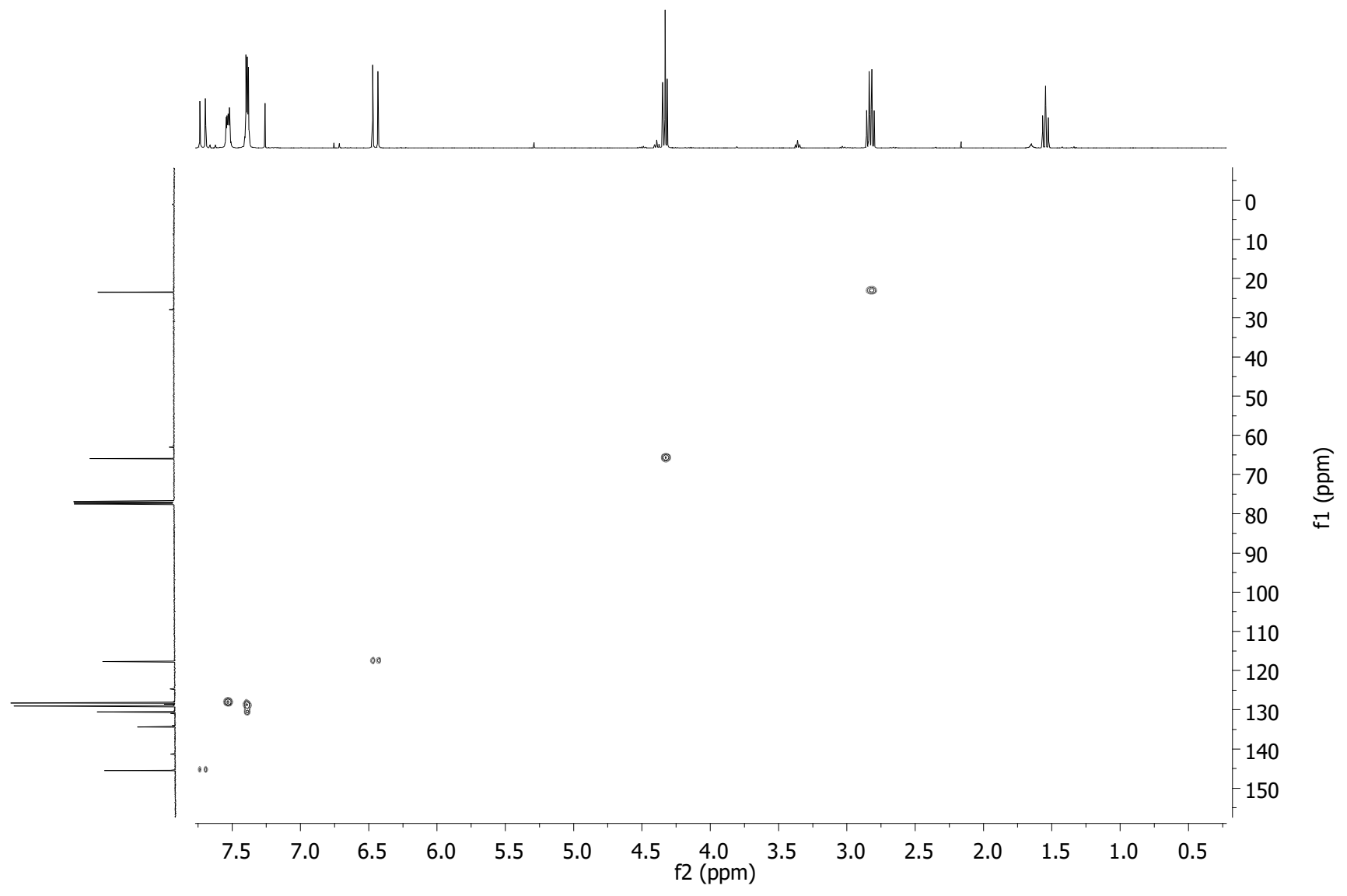

Figure S13. ${ }^{1} \mathrm{H}-{ }^{13} \mathrm{C}$ HSQC spectrum of $\mathbf{S H}-\mathbf{C i n n a m o y l}$ in $\mathrm{CDCl}_{3}$ 


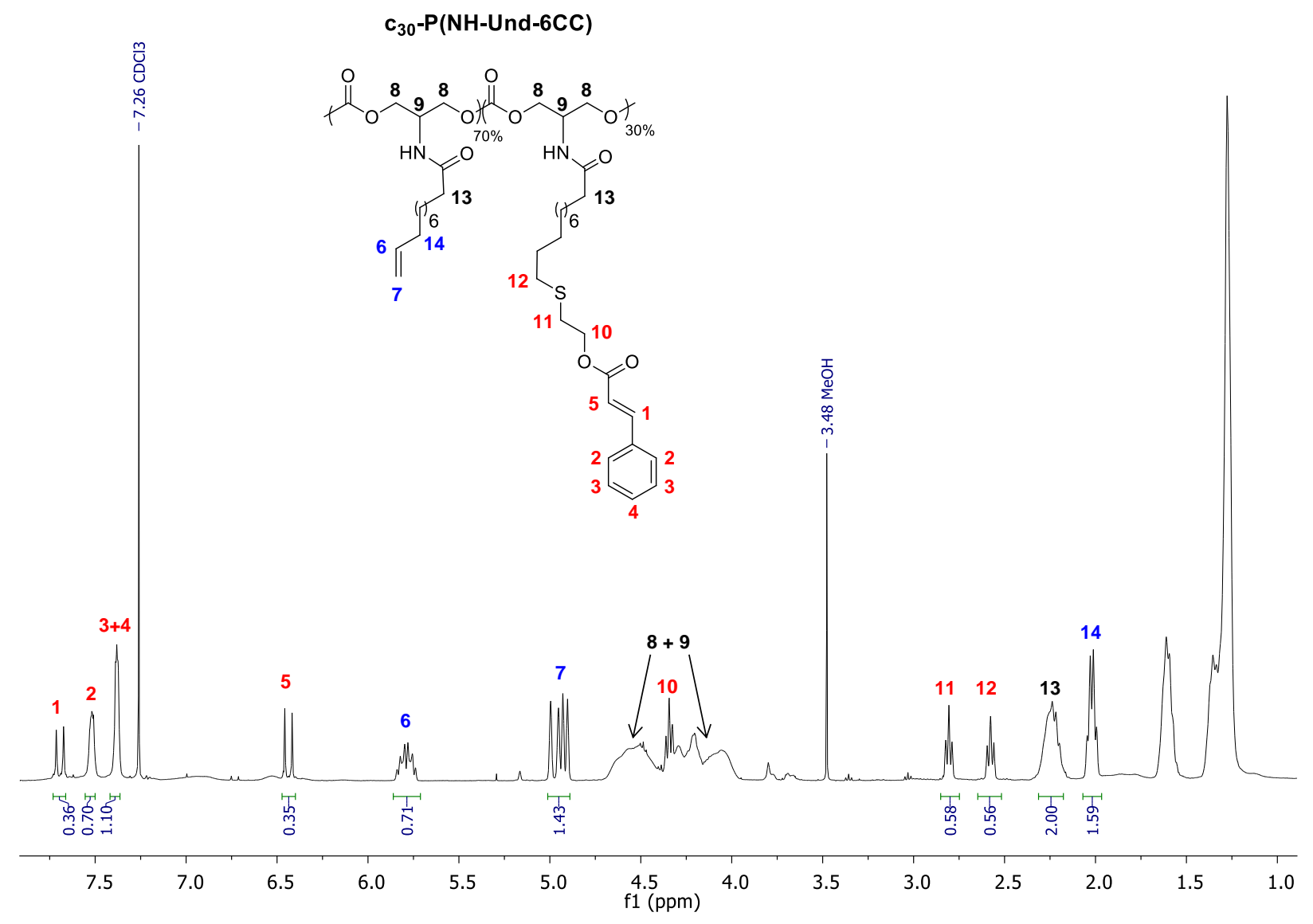

Figure S14. ${ }^{1} \mathrm{H}$ NMR spectrum of cinnamoyl-containing polycarbonate in THF. Example with 30 mol.\% of cinnamoyl content grafted on $\mathrm{P}(\mathbf{N H}-\mathbf{U n d}-\mathbf{6 C C})$

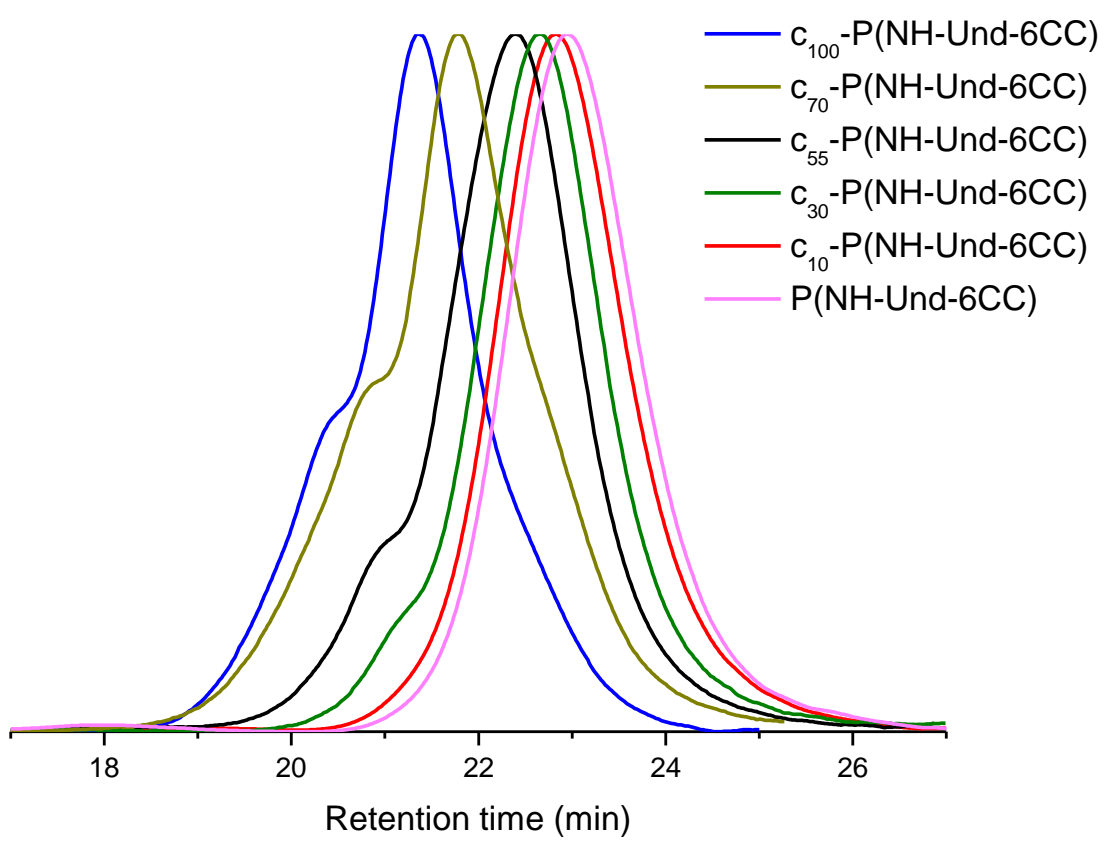

Figure S15. SEC traces of cinnamoyl-containing polymers in THF (Polystyrene standards) 


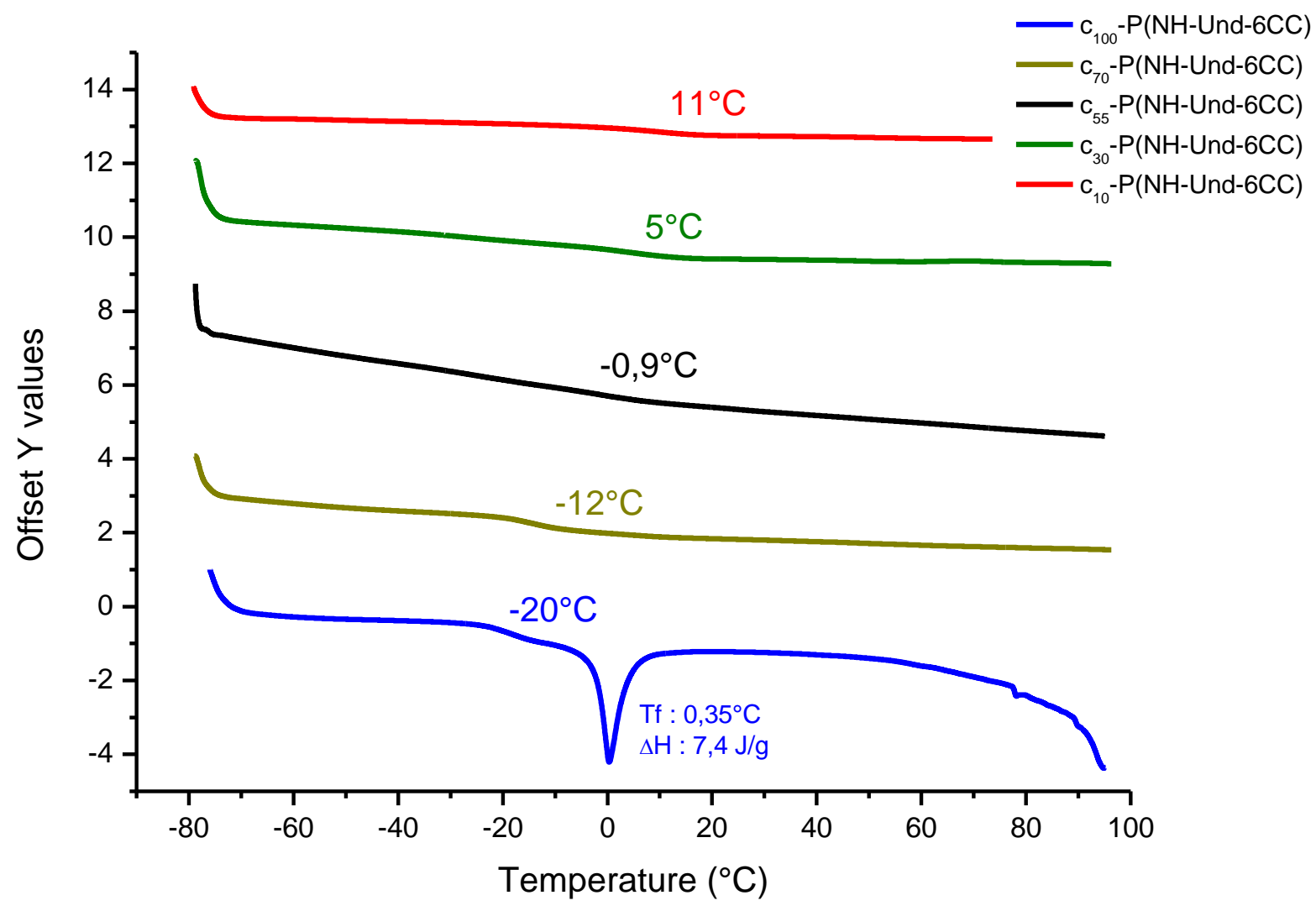

Figure S16. Second heating scans of DSC measurement of cinnamoyl-containing polycarbonates 


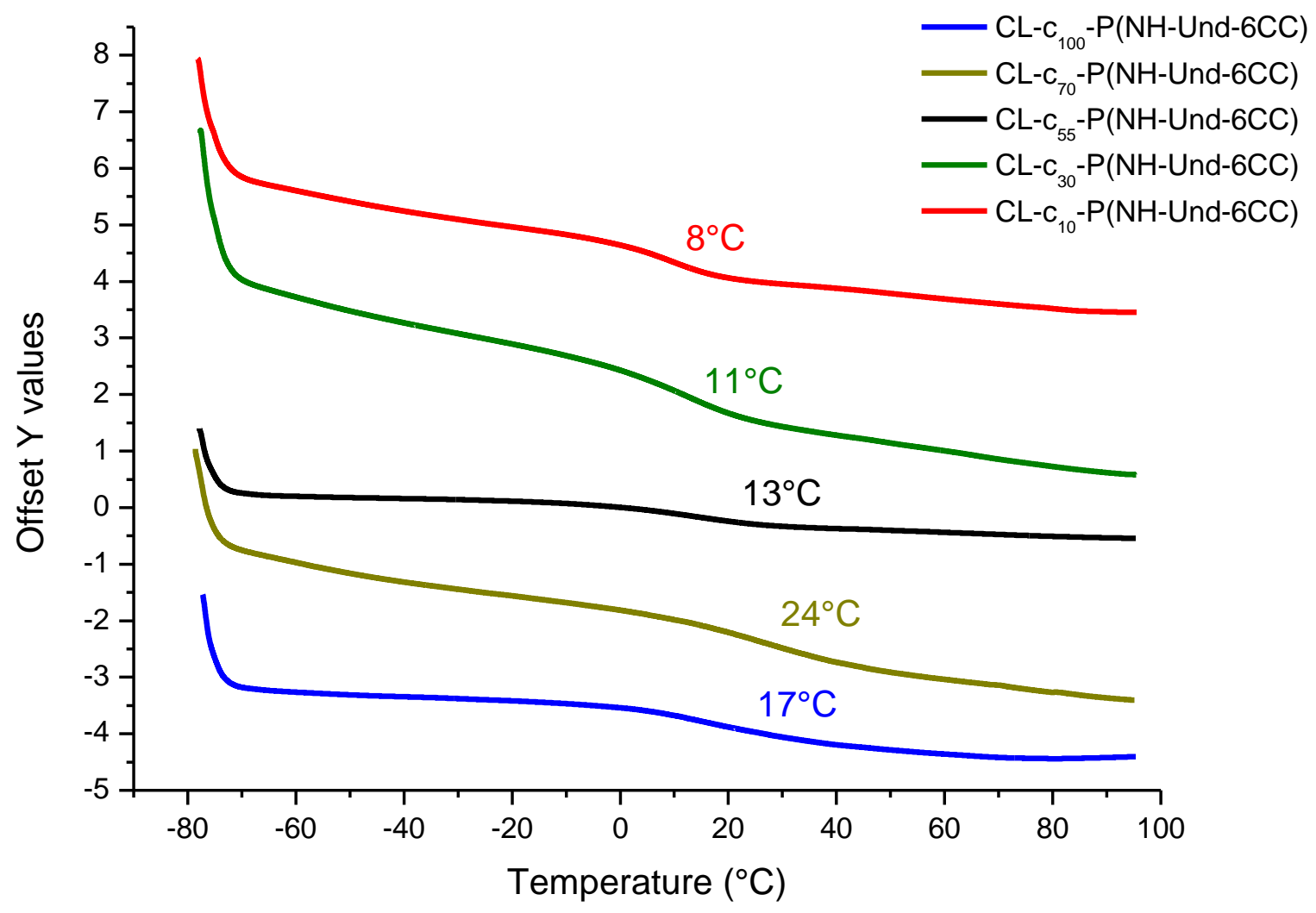

Figure S17. Second heating scans of DSC measurement of cross-linked cinnamoyl-containing polycarbonates 


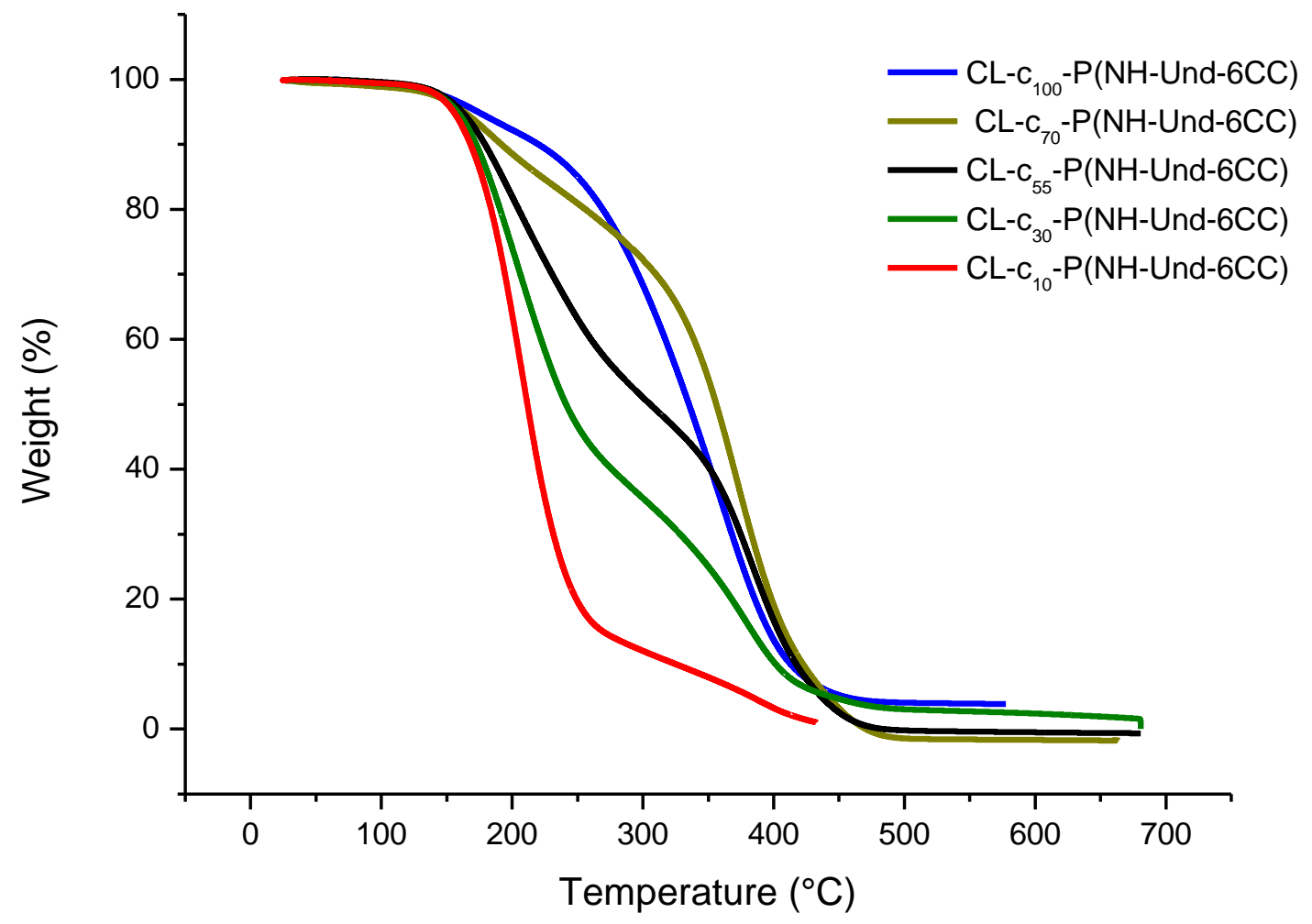

Figure S18: TGA analysis of cross-linked cinnamoyl-containinig polycarbonates 


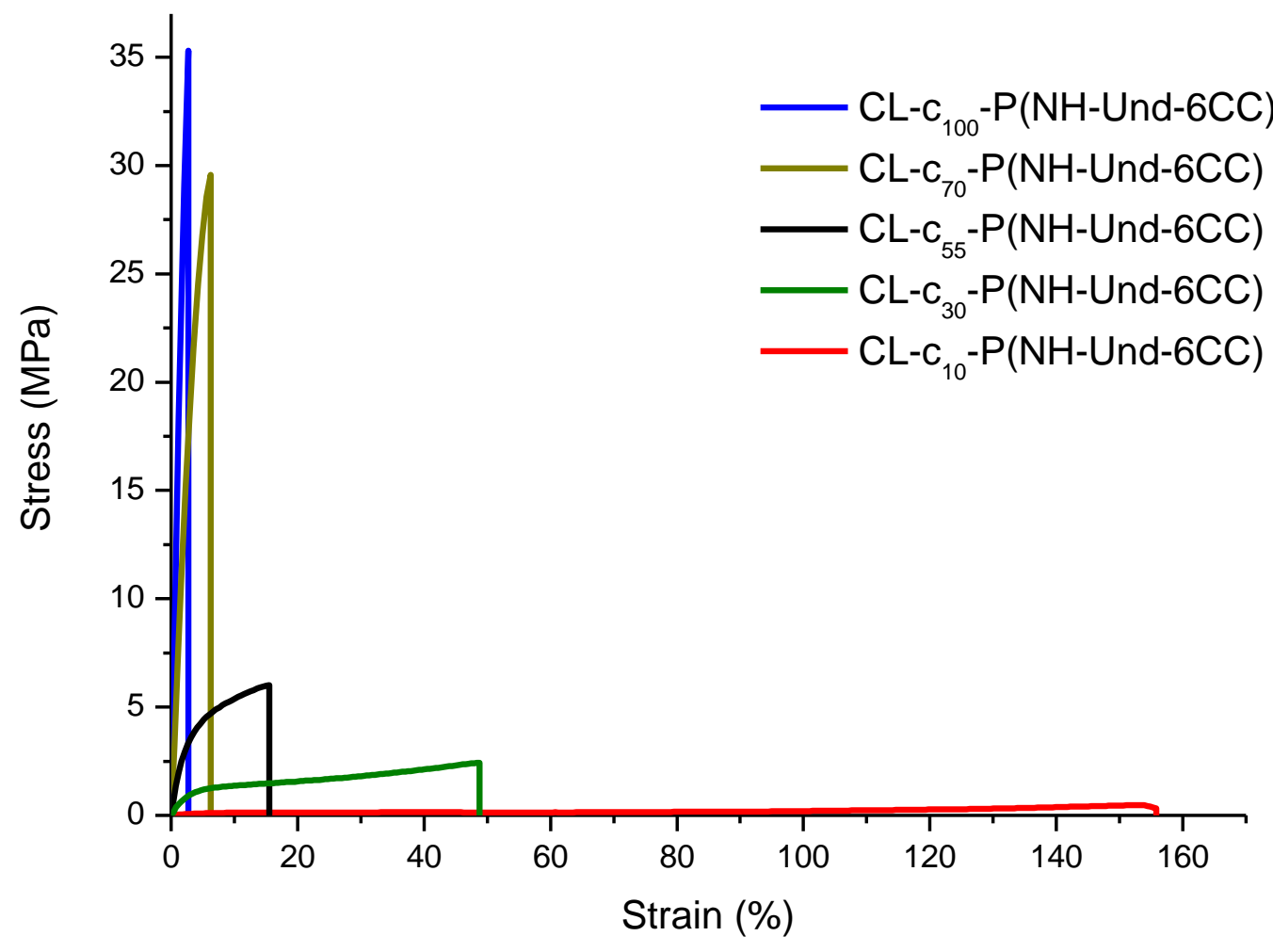

Figure S19. Stress - strain curves at room temperature of the polycarbonate networks prepared with the $[2+2]$ photochemical cyclo-addition of pendant cinnamoyl moieties 


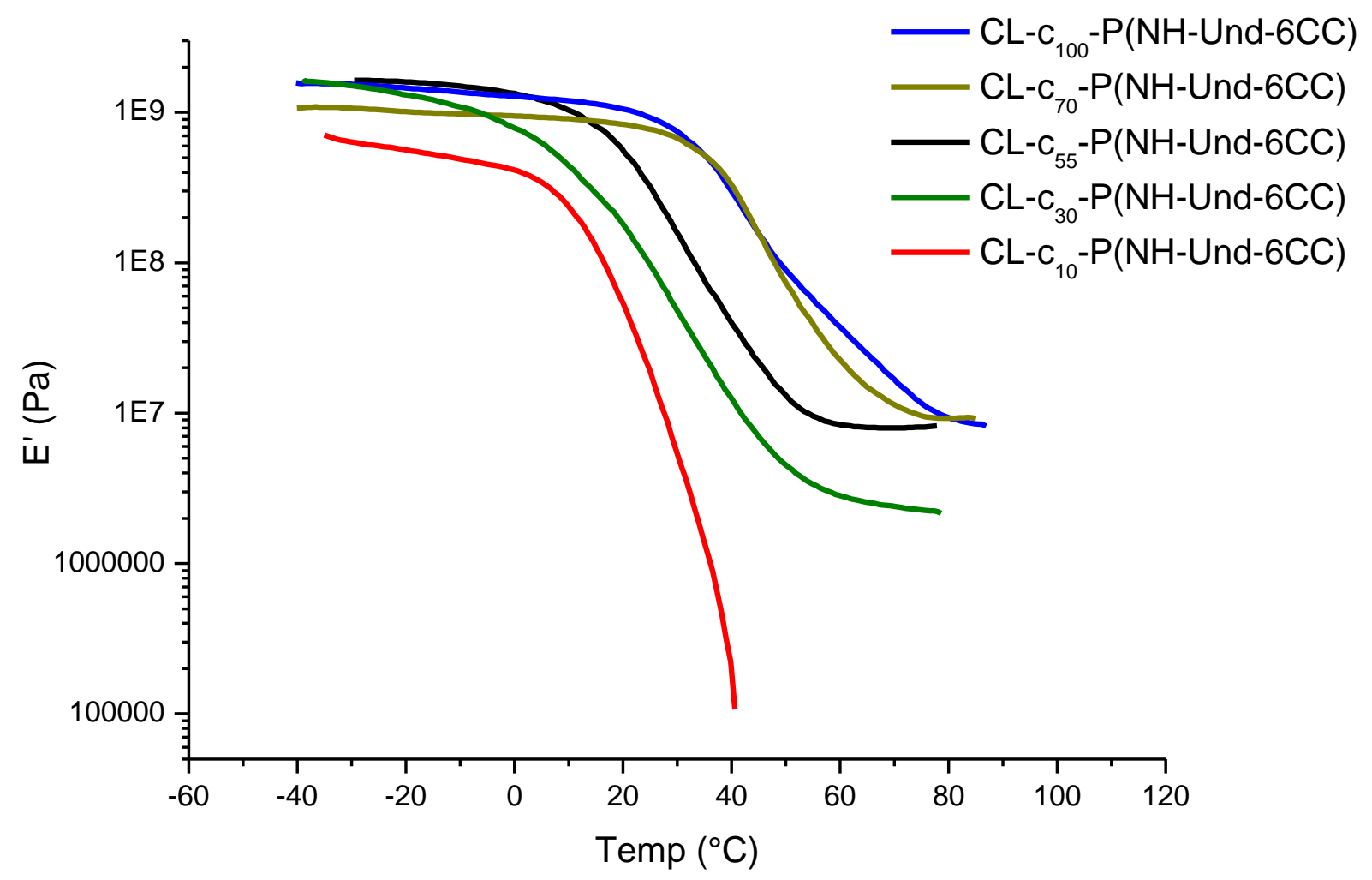

Figure S20. Thermo-mechanical experiments showing the tensile storage modulus $\left(\mathrm{E}^{\prime}\right)$ measured using DMA at an oscillation frequency of $1 \mathrm{~Hz}$

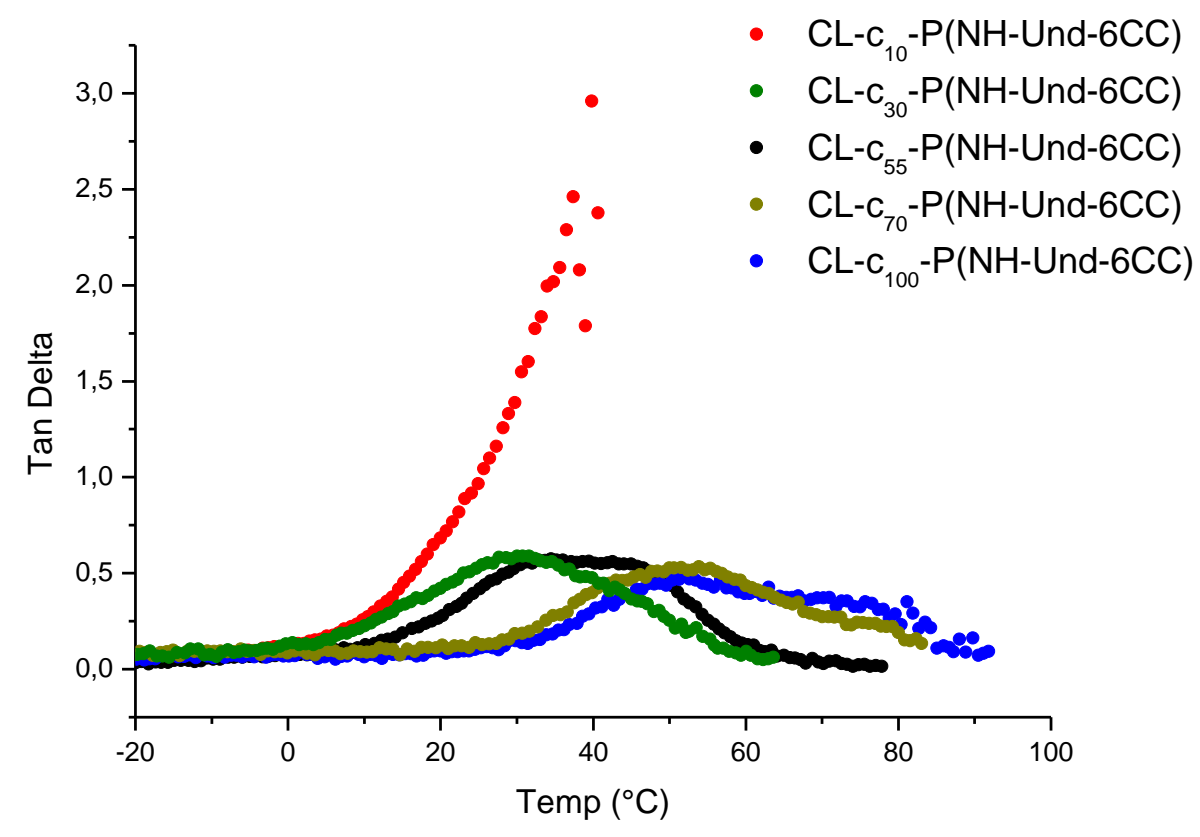

Figure S 21: Thermo-mechanical experiments showing Tan Delta measured using DMA at an oscillation frequency of $1 \mathrm{~Hz}$ 